University of Wollongong

Research Online

Faculty of Science - Papers (Archive)

Faculty of Science, Medicine and Health

2007

\title{
Stone Axe Technology in Neolithic South India: New Evidence from the Sanganakallu-Kupgal Region, Mideastern Karnataka
}

\author{
A Brumm \\ University of Wollongong, abrumm@uow.edu.au \\ Nicole Boivin \\ University of Oxford \\ Ravi Korisettar \\ Karnatak University \\ Jinu Koshy \\ Karnatak University \\ Paula Whittaker \\ West Yorkshire Archaeological Services
}

Follow this and additional works at: https://ro.uow.edu.au/scipapers

Part of the Life Sciences Commons, Physical Sciences and Mathematics Commons, and the Social and Behavioral Sciences Commons

\section{Recommended Citation}

Brumm, A; Boivin, Nicole; Korisettar, Ravi; Koshy, Jinu; and Whittaker, Paula: Stone Axe Technology in Neolithic South India: New Evidence from the Sanganakallu-Kupgal Region, Mideastern Karnataka 2007. https://ro.uow.edu.au/scipapers/5328 


\title{
Stone Axe Technology in Neolithic South India: New Evidence from the Sanganakallu-Kupgal Region, Mideastern Karnataka
}

\author{
Abstract \\ The transition to agriculture-and to settled village life-occurred at different times in various parts of the \\ world. Even within the Indian subcontinent, the Neolithic transition did not occur simultaneously across \\ the entire region; rather, Neolithic "pockets" developed at diderent moments in certain key areas within \\ the subcontinent. One such area is the South Deccan Plateau in South India, where the third millennium \\ b.c. saw the development of a novel Neolithic way of life that didered in crucial ways from Neolithic \\ lifeways in other parts of the subcontinent (Allchin 1963). This tradition was marked by a particular focus \\ on cattle and by the appearance of specific, perhaps ritual practices that featured the burning of large \\ quantities of cow dung and the resultant creation of ashmounds in the landscape (Allchin 1963; Boivin \\ 2004). This unique Neolithic tradition, while still relatively poorly understood compared to Neolithic \\ cultures in Europe and the Near East, has much to oder prehistorians attempting to understand the \\ changes that led to and accompanied domestication and sedentarization. It also has much to oder South \\ Asian scholars who wish to gain a better appreciation of the changes that led to complexity, political \\ economy, and state-level societies in South India (Boivin et al. 2005; Fuller et al. forthcoming). One key \\ requirement for such studies is a better understanding of the material culture changes that attended the \\ Neolithic transition, as well as the subsequent transition from the Neolithic to the Megalithic or Iron Age \\ (see Table 1 for period designations and chronology). Such understanding is currently poor, and this \\ essay oders an attempt to address this lacuna with respect to one particular form of material culture: \\ stone artifacts.

\section{Disciplines} \\ Life Sciences | Physical Sciences and Mathematics | Social and Behavioral Sciences

\section{Publication Details} \\ Brumm, A. R., Boivin, N., Korisettar, R., Koshy, J. \& Whittaker, P. (2007). Stone Axe Technology in Neolithic \\ South India: New Evidence from the Sanganakallu-Kupgal Region, Mideastern Karnataka. Asian \\ Perspectives: the journal of archaeology for Asia and the Pacific, 46 (1), 65-95.
}




\title{
Stone Axe Technology in Neolithic South India: New Evidence from the Sanganakallu-Kupgal Region, Mideastern Karnataka
}

\author{
(2) (0) (2) \\ ADAM BRUMM, NICOLE BOIVIN, RAVI KORISETTAR, \\ JINU KOSHY, AND PAULA WHITTAKER
}

The transition to Agriculture- and to settled village life-occurred at different times in various parts of the world. Even within the Indian subcontinent, the Neolithic transition did not occur simultaneously across the entire region; rather, Neolithic "pockets" developed at different moments in certain key areas within the subcontinent. One such area is the South Deccan Plateau in South India, where the third millennium B.C. saw the development of a novel Neolithic way of life that differed in crucial ways from Neolithic lifeways in other parts of the subcontinent (Allchin 1963). This tradition was marked by a particular focus on cattle and by the appearance of specific, perhaps ritual practices that featured the burning of large quantities of cow dung and the resultant creation of ashmounds in the landscape (Allchin 1963; Boivin 2004). This unique Neolithic tradition, while still relatively poorly understood compared to Neolithic cultures in Europe and the Near East, has much to offer prehistorians attempting to understand the changes that led to and accompanied domestication and sedentarization. It also has much to offer South Asian scholars who wish to gain a better appreciation of the changes that led to complexity, political economy, and state-level societies in South India (Boivin et al. 2005; Fuller et al. forthcoming). One key requirement for such studies is a better understanding of the material culture changes that attended the Neolithic transition, as well as the subsequent transition from the Neolithic to the Megalithic or Iron Age (see Table 1 for period designations and chronology). Such understanding is currently poor, and this essay offers an attempt to address this lacuna with respect to one particular form of material culture: stone artifacts.

Adam Brumm is affiliated with the Department of Archaeology and Natural History, Australian National University, Canberra. Nicole Boivin is associated with the Leverhulme Centre for Human Evolutionary Studies, University of Cambridge, UK. Ravi Korisettar and Jinu Koshy are affiliated with the Department of History and Archaeology, Karnatak University, Dharwad, India. Paula Whittaker is with the West Yorkshire Archaeological Services, Leeds, West Yorkshire, UK.

Asian Perspectives, Vol. 46, No. 1 (C) 2007 by the University of Hawai'i Press. 
Table i. Preliminary Chronological Model of Main Periods of Prehistoric Occupation at Sanganakallu-Kupgal

\begin{tabular}{|c|c|}
\hline PERIOD & OCCUPATION AND ACTIVITIES IN SANGANAKALLU-KUPGAL AREA \\
\hline ??† Mesolithic & $\begin{array}{l}\text { Intermittent site occupation on hilltop and plain. High } \\
\text { mobility and intensive hunting and gathering economy. }\end{array}$ \\
\hline 1900 & Creation of rock paintings at some sites (?). \\
\hline $\begin{array}{l}1900 \\
\text { Neolithic } \mathbf{A}^{\diamond}\end{array}$ & $\begin{array}{l}\text { Adoption of an increasingly settled lifestyle and establishment } \\
\text { of hilltop "village" sites. Cultivation of millets and pulses, } \\
\text { along with wheat and barley, accompanied by cattle and } \\
\text { sheep/goat pastoralism. Creation of ashmounds. }\end{array}$ \\
\hline 1700 & $\begin{array}{l}\text { Intensive stone on stone activities begin (grinding, cupule } \\
\text { creation). Beginnings of petroglyph/bruising and rock gong } \\
\text { creation (?). }\end{array}$ \\
\hline $\begin{array}{l}1700 \\
\quad \text { Neolithic } \mathbf{B}^{\diamond}\end{array}$ & Ashmound creation ceases. Village occupation continues. \\
\hline 1400 & \\
\hline 1400 & Intensification of craft production and trade activity. \\
\hline $\begin{array}{l}\text { Megalithic Transition } \\
1200\end{array}$ & $\begin{array}{l}\text { Specialized stone axe workshops and intensive quarrying and } \\
\text { axe production at Hiregudda }(1400-1200) \text {. Megalithic } \\
\text { pottery and burials begin. }\end{array}$ \\
\hline $\begin{array}{l}1200 \\
\text { Classic Megalithic/ } \\
\text { Early Iron Age }\end{array}$ & $\begin{array}{l}\text { All hilltop villages abandoned. Settlement moves onto plain. } \\
\text { Intensive megalith production on plain. Iron introduced c. } 800 \\
\text { BC. Stone on stone activities less intensive. }\end{array}$ \\
\hline$? ?^{\dagger}$ & \\
\hline
\end{tabular}

\section{THE STONE ARTIFACTS}

Recent archaeological investigations at the Neolithic sites at SanganakalluKupgal, in the district of Bellary in mideastern Karnataka, South India, produced a very large assemblage of worked stone artifacts. As with many Southern Neolithic sites, sophisticated chert and chalcedony pressure microblade technology was encountered (e.g. Allchin 1963; Ansari 1988; Dufresne et al. 1998; Foote 1916; Subbarao 1948). Various other characteristic Neolithic tool types, such as granite querns and grindstones, also formed a significant component of the assemblage. Interestingly, however, of the $>600,000$ stone artifacts recovered during recent investigations, the vast majority (80-90 percent) comprised dolerite debitage from the manufacture of bifacial edge-ground axes. This immense quantity of dolerite debitage seemed to indicate a particularly intense focus on the production of stone axes at Sanganakallu-Kupgal during the Neolithic period, a possibility first raised by Robert Bruce Foote in the late 1800s (Foote 1887).

Several eminent Southern Neolithic scholars and South Asian prehistorians, most notably Foote (1887, 1916), Worman (1949), Subbarao (1948), Allchin (1957, 1960, 1962, 1963) and others (Deo and Ansari 1965; Sankalia 1988; Sankalia et al. 1971; Wheeler 1948, 1959), have undertaken research into the distribution and evolution of Neolithic stone axe industries of South India (see Korisettar et al. 2001 for review), including those of the Bellary District (e.g., Allchin 
1957). These studies, however, have focused mostly on type-based morphological analyses of artifact assemblages (see Adams and Adams 1991; Bisson 2000; Dunnell 1986), with the distribution through time and across space of formal variation in artifacts used to document the history of the development and migration of specific prehistoric cultures (Lyman et al. 1997; Trigger 1989; but see Inizan and Lechevallier 1990, 1995, 1997; Inizan et al. 1992, 1994 for technological studies of microblade production in northern India, Pakistan, and elsewhere). Despite decades of research, little insight is provided into the technology and technical processes of Neolithic axe production (e.g., Edmonds 1990; Inizan et al. 1999; Pelegrin et al. 1988) and the wider social and economic dimensions such practices may illuminate (Dobres 2000; Lemonnier 1986, 1992).

Given this situation-and in light of the ongoing destruction of Neolithic sites in the Sanganakallu-Kupgal area due to large-scale industrial quarrying (discussed below) - we became concerned with documenting in as much detail as possible the archaeological evidence for dolerite axe manufacture at Sanganakallu-Kupgal. This entailed investigation into (1) the spatial distribution and patterning of dolerite reduction areas; (2) survey and recording of quarried dolerite outcrops; (3) the technological organization of axe manufacture; and (4) the chronology of axe production in the study area. The purpose of this essay is to discuss some preliminary results from our investigations and to highlight avenues for future archaeological research at Sanganakallu-Kupgal and elsewhere in South India.

\section{ARCHAEOLOGICAL EVIDENCE FOR AXE PRODUCTION AT HIREGUDDA}

Sanganakallu-Kupgal refers to a cluster of granite hills that are straddled by the villages of Sanganakallu and Kupgal in the Bellary District of Karnataka (Fig. 1). The hills and the immediately surrounding plains are home to a significant concentration of archaeological sites that have recently been the focus of detailed archaeological investigation as part of the Sanganakallu-Kupgal Project (see Boivin et al. 2005). This work has led to renewed study of a hill first identified by Robert Bruce Foote as an axe production site in the late nineteenth century (Foote 1887, 1916) but largely overlooked by subsequent researchers. The hill is known locally as Hiregudda (which means "Big Hill"), but it is commonly referred to in the archaeological literature as Kupgal Hill (and sometimes, in early British works, as Peacock Hill; see Fig. 2).

Investigations by the Sanganakallu-Kupgal Project led to the discovery of various lithic production-related localities at Hiregudda, including an axe production area on a medium-sized plateau in the southeast part of the large and topographically complex hill. This noteworthy locality has been labeled Area A according to the area designation system employed by the Sanganakallu-Kupgal Project (Fig. 2). Area A features a particularly heavy surface scatter of early and late-stage dolerite bifacial axe manufacturing debris, including axe blanks and axes. It has been extensively modified by recent sediment mining and commercial granite quarrying activities, which have destroyed part of the area and exposed strata bearing thick deposits of similarly flaked dolerite material (Fig. 3).

A stone-lined circular structure (labeled Feature 1) located on the northeast side of Area A has been the focus of intensive archaeological investigation (Fig. 4). Feature 1 measures approximately $7 \mathrm{~m}$ in diameter and is composed of an outer 


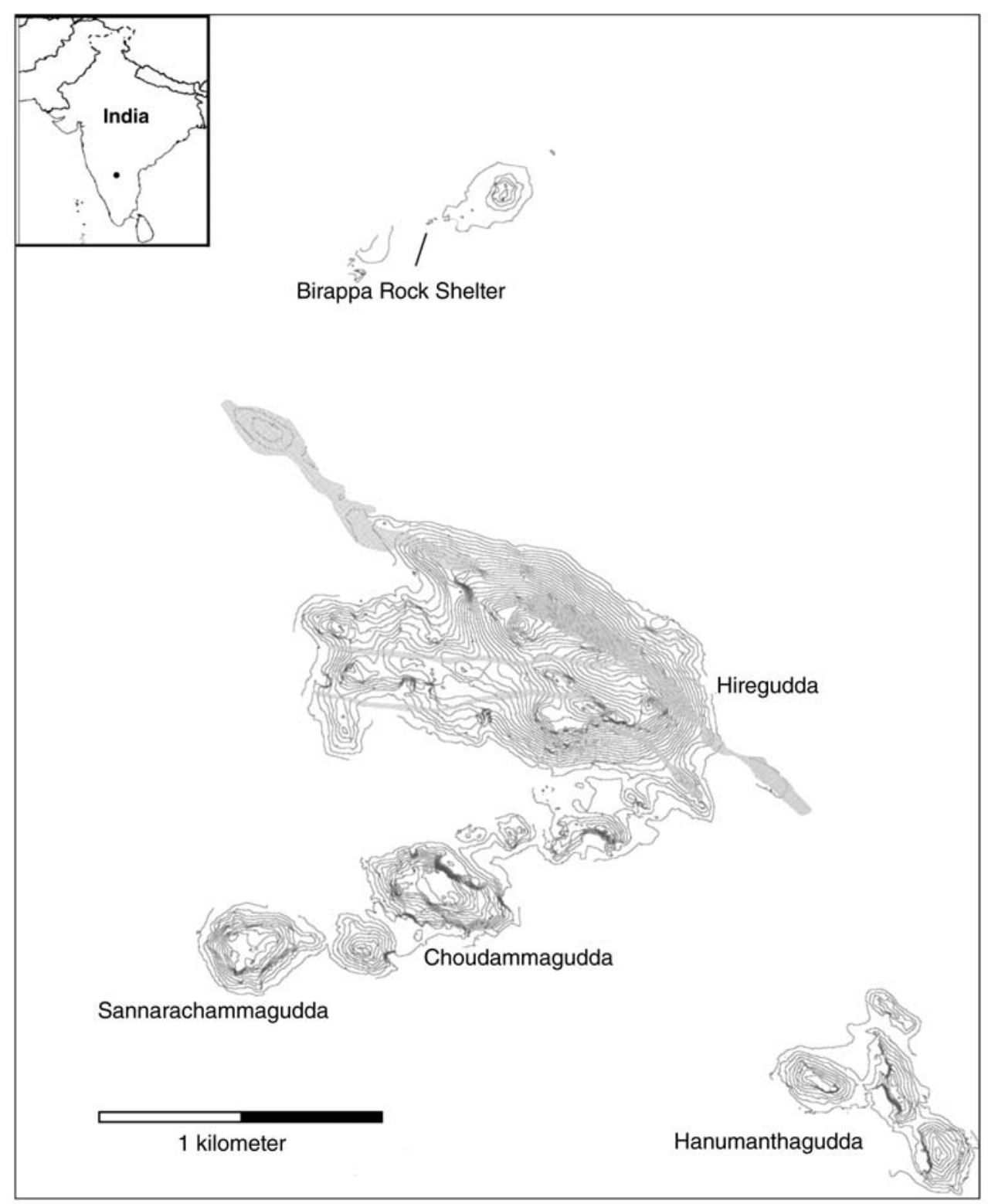

Fig. 1. Map showing the Sanganakallu-Kupgal area and its location within the Indian subcontinent. Note that gudda is the Kannada word for hill. Gray shaded areas represent dolerite dykes, all of which are found on Hiregudda.

ring of granite stones varying in size from $20 \mathrm{~cm}$ to over $1 \mathrm{~m}$ in diameter. A smaller ovoid arrangement of granite stones (labeled Feature 3), with dimensions of c. $4.5 \times 3 \mathrm{~m}$, forms an apparent internal division inside the northern section of the enclosure. The granite stones comprising Feature 1 are all unshaped natural boulders, although a few cupule markings were noted on the upper surfaces of 


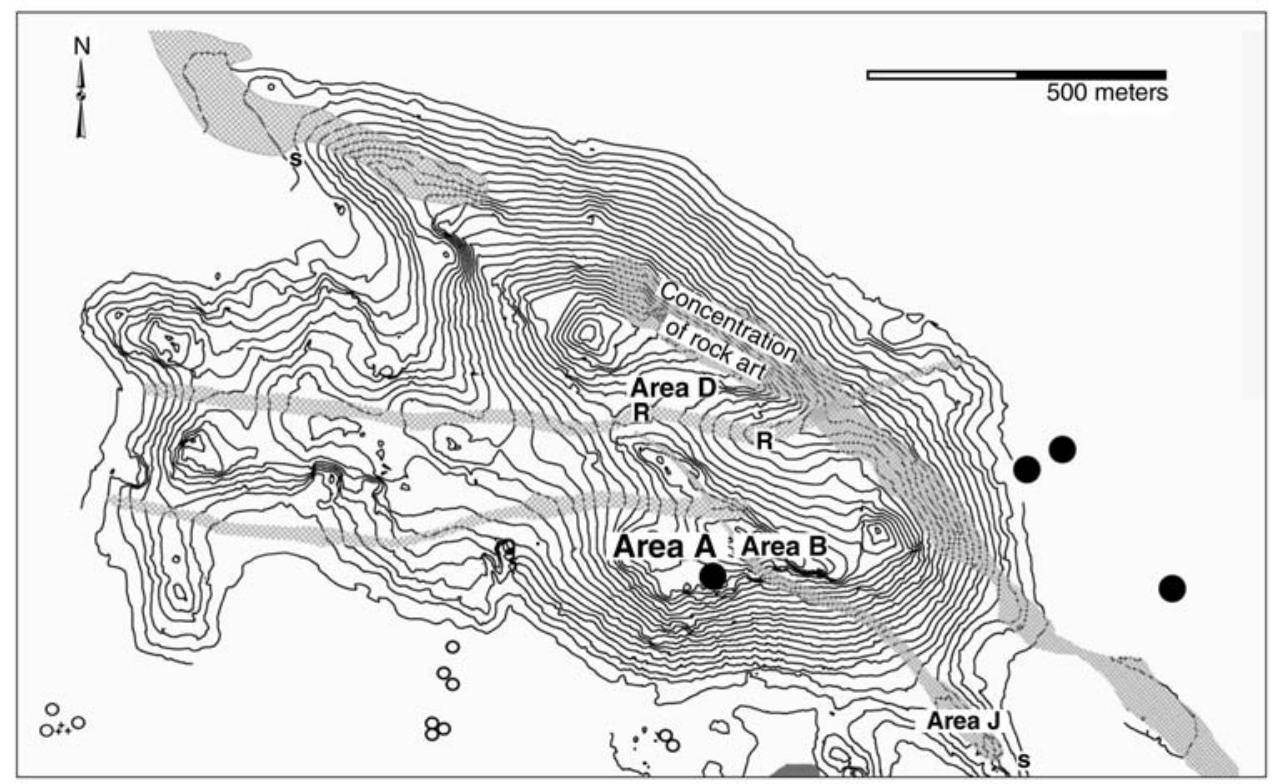

Fig. 2. Map showing Hiregudda and some of the main archaeological areas investigated as part of the Sanganakallu-Kupgal Project. Gray shading indicates dolerite dykes. Area A is the richest archaeological locality on the hill and contains abundant evidence for occupation followed by specialized axe production. Area B (Upper Quarry) includes evidence for dolerite quarrying and the production of granite querns, as well as both dolerite and chert tools. Area D is a terraced area where several infant urn burials were exposed. Area J (Lower Quarry) contains abundant evidence for Neolithic dolerite mining activity, including well-preserved quarry pits. Other features: S: spring; R: reservoir; large filled dots: ashmounds; small open dots: Megalithic stone circles; plus $(+)$ signs: cairns or dolmens.

some. In the southeast corner of the structure, a gap $70 \mathrm{~cm}$ wide in the outer circle of stones seems to have functioned as an entranceway. Posts for supporting walls and roofing may have been placed in between the stones, although no direct evidence for this (i.e., postholes) was found. A dense scatter of dolerite debitage was visible on the ground surface inside and in the general vicinity of Feature 1. Several meters to the southeast of Feature 1 and slightly downslope, modern sediment mining has created a $20 \times 15 \mathrm{~m}$ extraction pit in the earth. This disturbance has exposed in section several thickly stratified layers of dolerite debitage intermixed with varying quantities of pottery and bone. These archaeological deposits relate both spatially and chronologically to Feature 1. A very small trench, called Trench 1, was excavated in this area. Despite its limited size (c. $2 \mathrm{~m}$ squared, though $1.6 \mathrm{~m}$ in depth), it produced a massive quantity of axemanufacturing material, suggesting the area functioned as a substantial lithic disposal site in prehistoric times.

Feature 1 was excavated to bedrock in three quadrants. The floor deposits extend to a maximum depth of c. 500-600 $\mathrm{mm}$ below the ground surface (Fig. 5). Stratigraphic contexts in Feature 1 are divided into two broad phases related to the temporal occupation of the structure: early occupation and late occupation. Relatively thin layers of pale brown-gray ashy silt and compact brown silt 


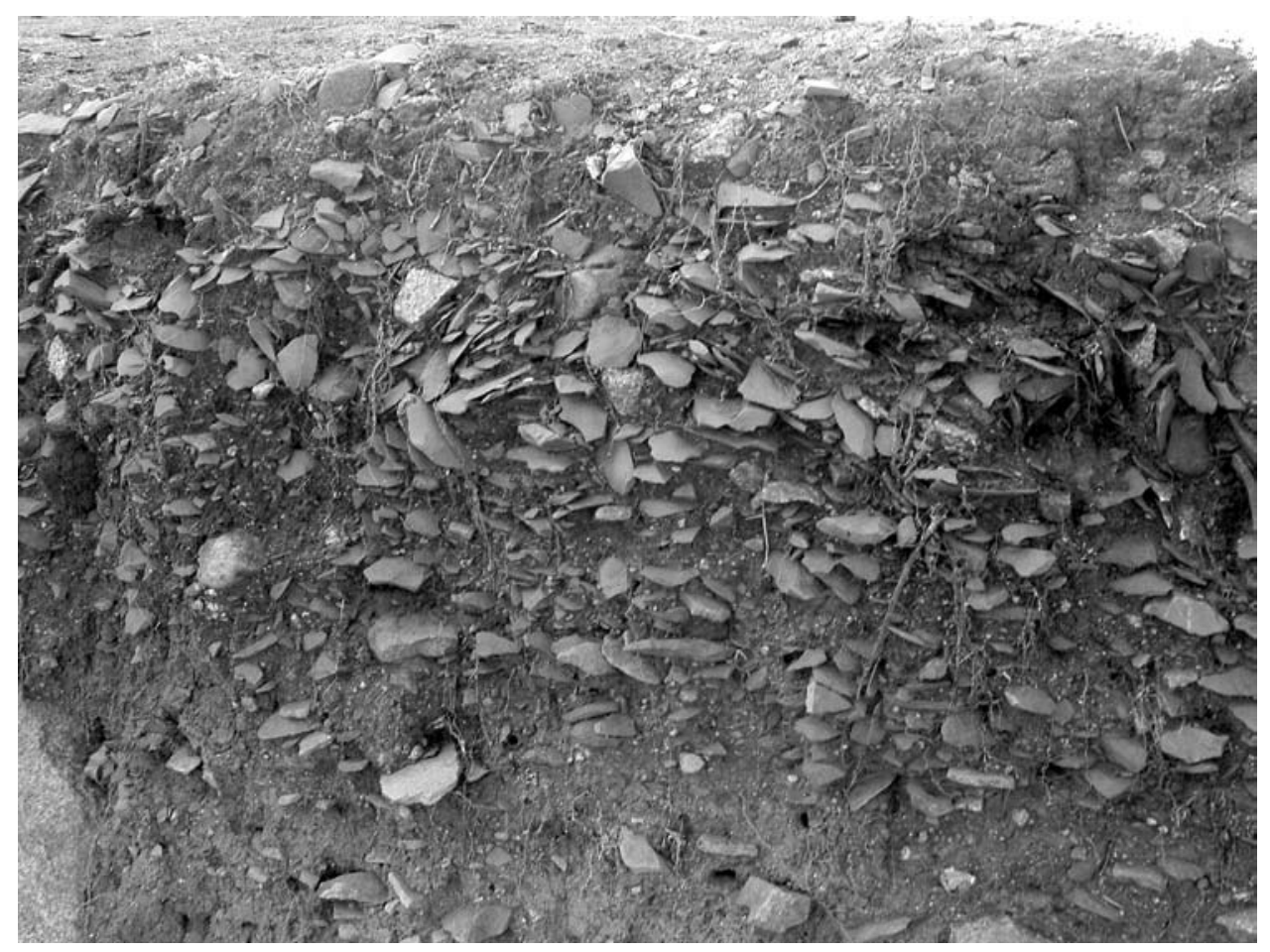

Fig. 3. Thickly stratified dolerite debitage layers revealed by modern quarrying and sediment extraction activities in Area A.

lying atop granite bedrock represent the early occupation phase. Artifact densities are comparatively low in these bottom layers, suggesting the floor of the dwelling may have been kept fairly clean and free of refuse. Considerably thicker stratified layers of rich clayey silt and pale brown silt admixed with extremely dense lithic deposits represent the late occupation phase. Large quantities of dolerite debitage and other rubbish (i.e., potsherds and animal bone fragments) were allowed to accrue in the floor plan of the dwelling during this phase. Most of the lithic debris accumulated in the northwest quadrant toward the back of the structure. The degree of patination on most lithics suggests that artifacts lay exposed on the ground surface for extended periods during the late occupation phase, indicating periodic abandonment of the structure. The weathered state of some recovered bone fragments adds further support to this possibility.

The stone, ceramic, and bone assemblages from the early occupation layers in Feature 1, coupled with stratigraphic evidence and the spatial distribution of artifacts, imply that the structure was the focus of domestic habitation during its early life history. These lower layers represent a fairly mixed lithic assemblage. While dolerite predominates, there is evidence not only for dolerite axe manufacture and reworking but also for unstructured quartz reduction and the production of chert, chalcedony, and quartz/quartz crystal pressure microblades. This would seem to indicate that stone knapping activities and tool use were fairly varied in 


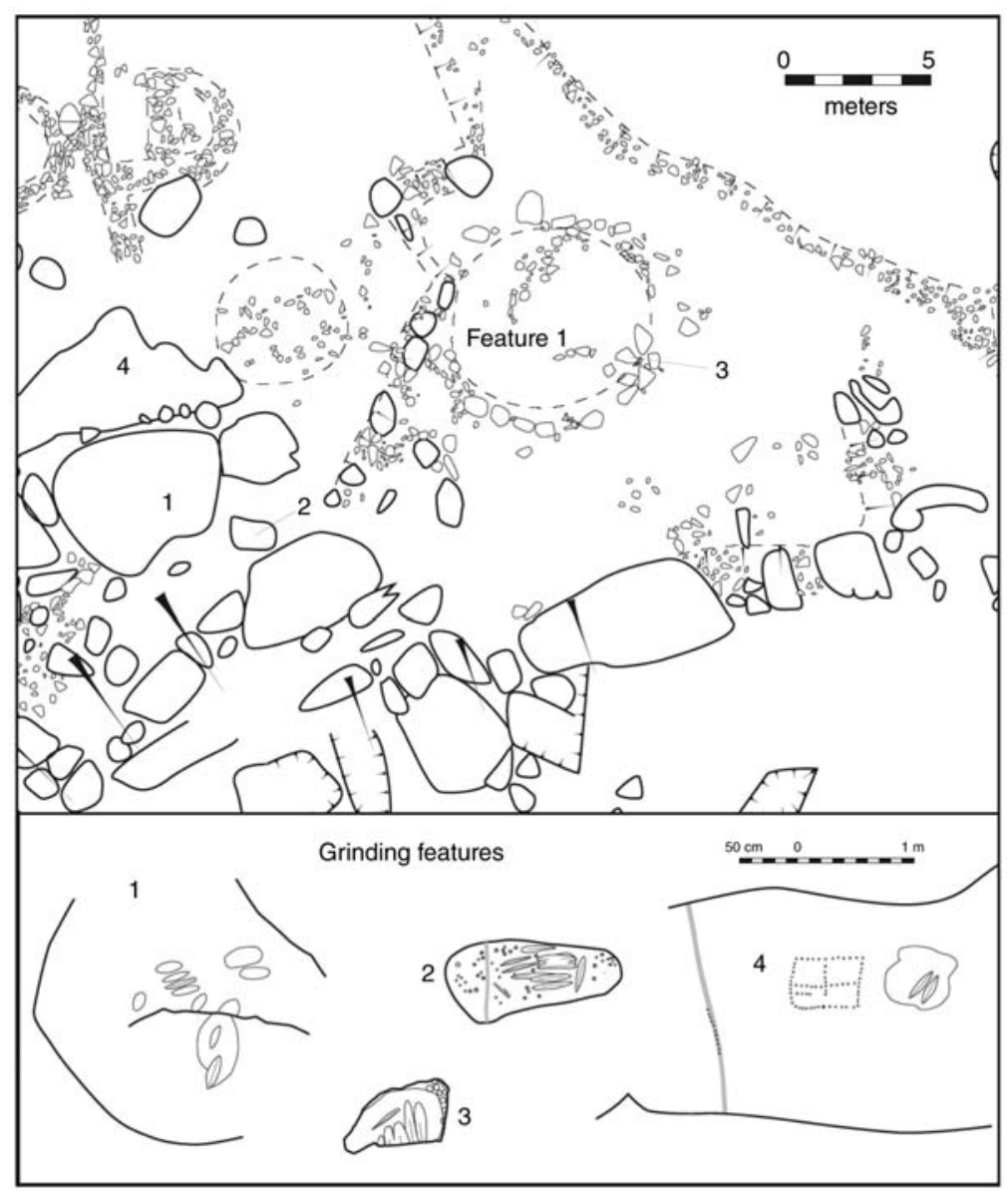

Fig. 4. Plan view of stone-lined circular enclosure (Feature 1) situated in Area A. Also depicted are rock surfaces with axe-grinding grooves $(1-4)$ and cupule-like grinding hollows (2-3), petroglyphs (4), and pecked and ground quartz veins $(2,4$; quartz veins are represented by gray shaded lines) associated with axe-grinding grooves. (Courtesy of Paul Masser)

the early life history of Feature 1. By contrast, during the late occupation phase there is little evidence for a continuance of domestic-oriented activities inside the structure. From a statistical perspective, there is virtually no evidence for the flaking of stones other than dolerite. The immense volume of dolerite debitage recovered from the upper portion of the stratified deposits suggests that Feature 1 functioned as a specialist axe production "workshop" during the later phase of occupation. Given the degree of weathering on most artifacts, it is probable that habitation of Feature 1 during this period was seasonal in nature. In both the early and late occupation phases (but particularly toward the latter phase of habitation) of Feature 1, there is evidence for symbolic and possibly ritual activities in the form of several fragments of ceramic figurines, some faceted pieces of red ochre, a number of stone and copper beads, and a small assemblage $(\mathrm{N}=20)$ of dolerite flake debitage with nonfigurative imagery incised on the exterior cortical surfaces (see Brumm et al. 2006). 


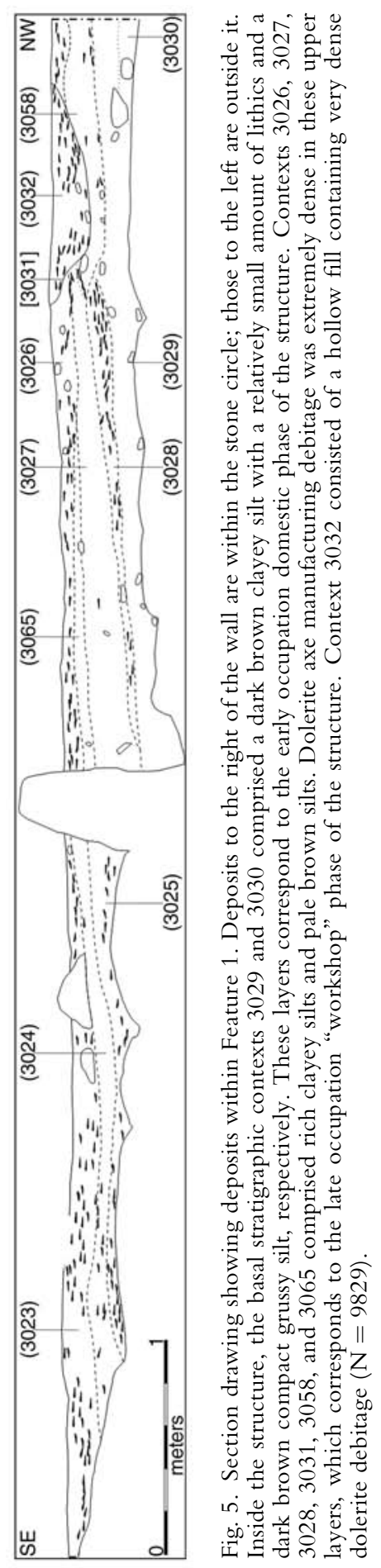




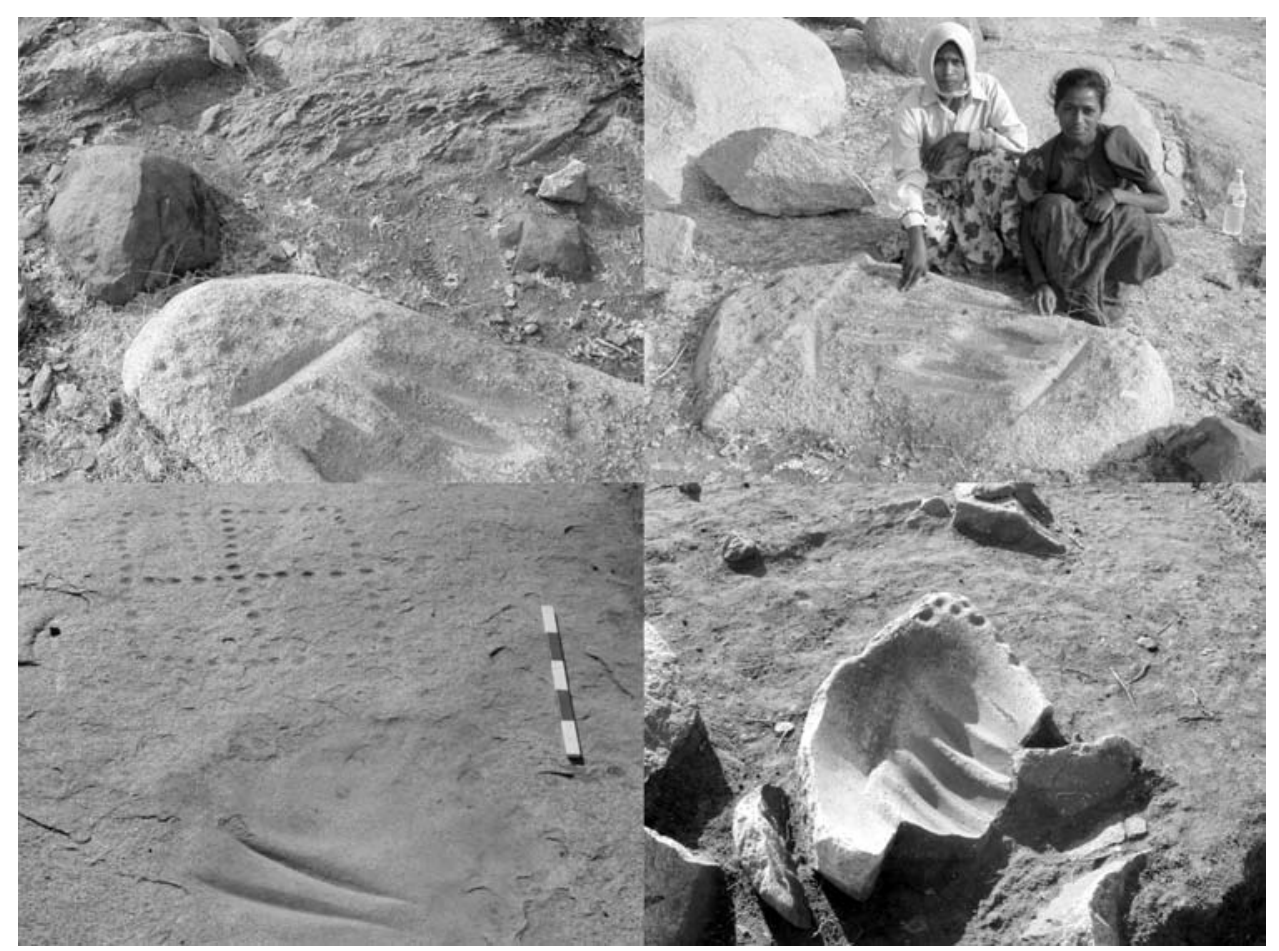

Fig. 6. Axe-grinding grooves on granite rocks in association with cupules and petroglyphs in and around Feature 1. The granite quern in the bottom right frame is situated just inside the southeast entranceway to the circular structure and features a cluster of several parallel linear axe-grinding grooves.

The inference that Feature 1 functioned as an axe manufacturing workshop is lent additional support by the presence of several clusters of axe-grinding grooves on granite rocks situated in and around the structure (Fig. 6; see also Fig. 4). Survey and mapping within the vicinity of Area $A$ has also led to the discovery of at least two nearby quarried outcrops of dolerite (Fig. 7). These quarries were labeled the Upper Quarry (Area B) and the Lower Quarry (Area J). They are both located at different elevations along the same linear trap dyke within several hundred meters of the Feature 1 axe-production workshop (see Fig. 2). The Lower Quarry, situated at the southeast foot of Hiregudda, has recently been exposed in section as a result of modern industrial granite quarrying, revealing evidence for subterranean mining pits into the trap dyke (Fig. 8). There are also clear signs of on-source reduction of raw dolerite in and around these pits (see below), which average around $2-3 \mathrm{~m}$ in width and $1 \mathrm{~m}$ in depth. Prehistoric mining pits were recorded along the entire length of the c. $100 \mathrm{~m}$ exposed section, hinting at the former dimensions of the quarry.

Only limited test-pit excavation at the Upper Quarry in Area B has taken place so far. However, preliminary research at both locales indicates a focus on the extraction of naturally weathered rectangular blocks and slabs of dolerite, probably by digging directly down into subterranean deposits and extracting suitably shaped 


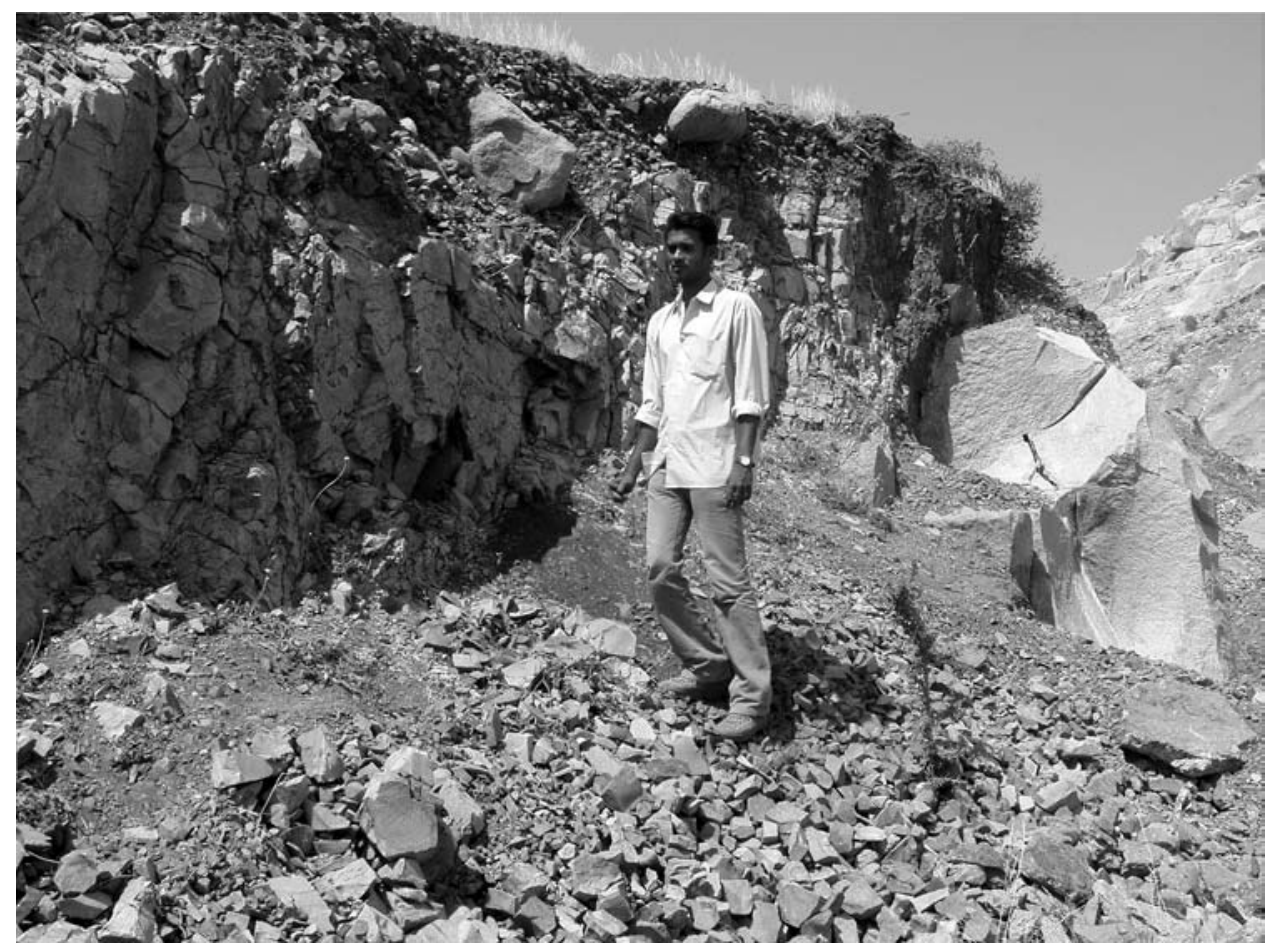

Fig. 7. The Lower Quarry (Area J), southeast foot of Hiregudda. A vertical section of the dolerite dyke has been exposed by modern granite extraction activities (a freshly split granite boulder is visible in the background to the right). The Neolithic quarry layer is visible at the top of the exposed dyke. The talus slope on which coauthor Jinu Koshy is standing is composed of a mixture of lithic material eroding from the quarry layer and unmodified dolerite pieces that have recently weathered from the underlying rock mass.

pieces, which were reduced on source into large bifacial "rough-outs." Although these quarries need to be investigated further, preliminary observations suggest that exploitation of dolerite outcrops on Hiregudda during the Neolithic period was large scale and systematically organized.

\section{ANALYTICAL METHODOLOGY}

The lithic analysis component of the Sanganakallu-Kupgal Project focused on modeling stone artifact reduction sequences employed at Hiregudda. In the context of lithic analyses, sequence models are aimed at reconstructing the technological modifications that a stone underwent between the time of raw material procurement and the final discard of the artifact into the archaeological record (Bleed 1991, 2001; Chazan 1997; Dobres 2000; Edmonds 1990; Moore 2003a, b, c, 2004; Pelegrin et al. 1988; Pétrequin et al. 1998; Schlanger 1996; Sellet 1993; Shott 2003). The focus is on the methods employed to reduce stones rather than on the tool types themselves, providing insight into the technological behavior of knappers (Chazan 1997: 720). 


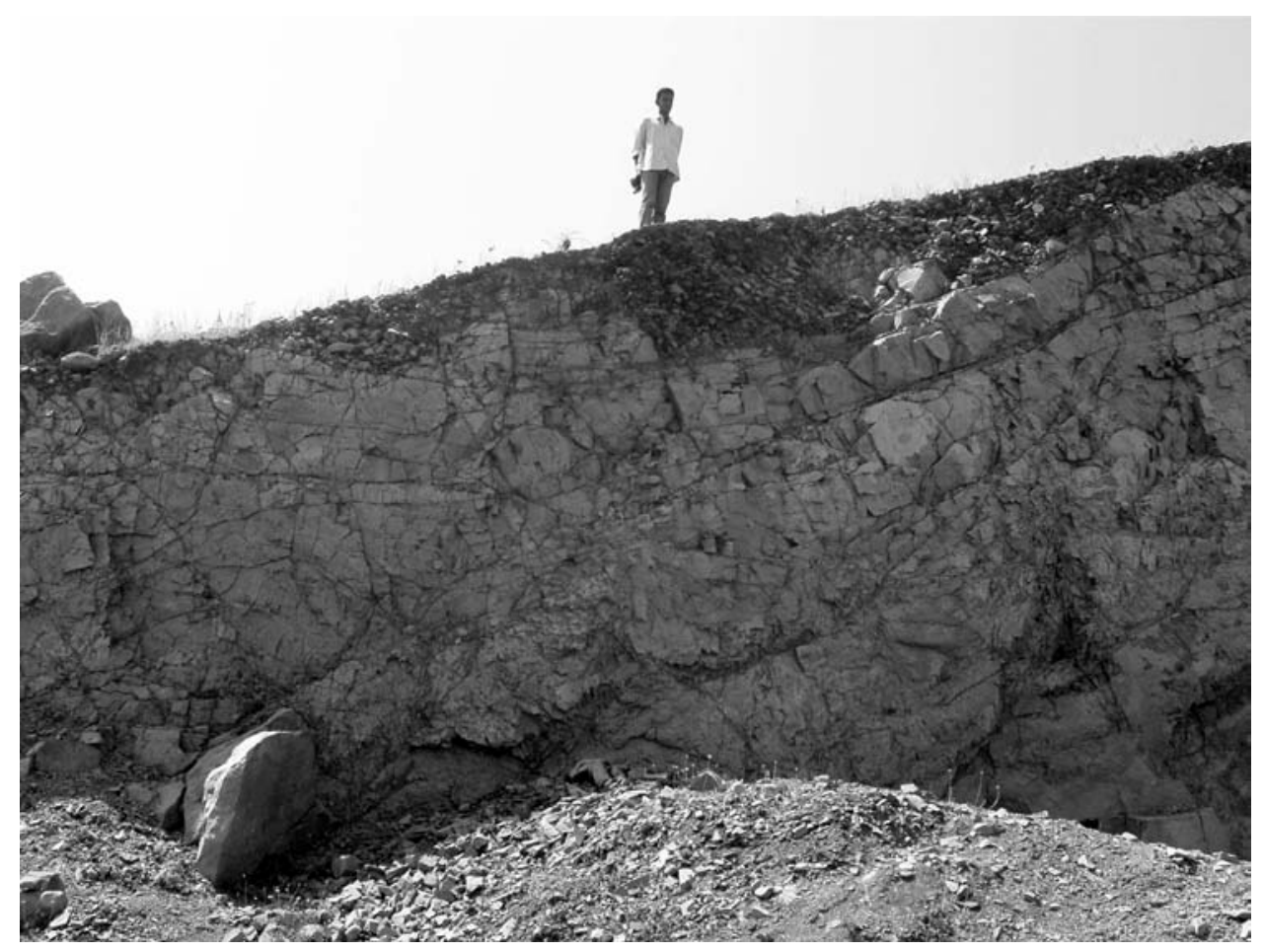

Fig. 8. A series of Neolithic mining pits seen in section along the exposed dolerite dyke at the Lower Quarry (Area J).

Technological observations derived from flake scar overlap analysis were tested via an informal knapping program conducted by two of the authors (Brumm and Koshy), creating a "feedback loop" by which hypotheses generated from the examination of formed objects (both artifactual and experimental) and comparative examination of technical attributes on individual debitage specimens aided the fine-tuning of the definition of technological types and the morphological boundaries between them (Moore 2003c).

A representative sample of the dolerite assemblage was sorted into the debitage and formed object types listed in Table 2. Some 296,730 dolerite artifacts from 21 stratigraphic contexts across Feature 1 and Trench 1 in Area A were roughly sorted and catalogued. A sample of artifacts from each of these contextscomprising 83,858 artifacts in total-was sorted into discrete technological categories and analyzed.

\section{AXE MANUFACTURING METHODS AT HIREGUDDA}

Axe production processes in Area A seem, on current evidence, to have been carried out mainly within Feature 1. The abundance of surface stone scatters across Hiregudda suggests there may have been other such discrete axe production workshops and reduction areas located in the area during the Neolithic. However, this is the only such feature that has been identified and investigated to date. 
Table 2. Summary of Technological Types Identified in the Dolerite Assemblage from Feature i and Trench i in Area A, Hiregudda

\begin{tabular}{|c|c|c|c|}
\hline TYPE & FEATURE I & TRENCH I & TOTAL \\
\hline Early reduction flake & 16,406 & 5152 & 21,558 \\
\hline Nonflake debitage & 50,959 & 8069 & 59,028 \\
\hline Biface thinning flake & 1421 & 1063 & 2484 \\
\hline Redirecting flake & 24 & 12 & 36 \\
\hline Retouched flake & 108 & 78 & 186 \\
\hline Residual flake (erraillure) & 10 & - & 10 \\
\hline Contact removal flake & 2 & 1 & 3 \\
\hline Microdebitage $(<10 \mathrm{~mm})$ & $*$ & $*$ & * \\
\hline Edge-ground axe & 2 & - & 2 \\
\hline Axe blank & 69 & 56 & 125 \\
\hline Axe reworking flake & 102 & 48 & 150 \\
\hline Edge-ground "chisel" & 3 & 1 & 4 \\
\hline Multiple platform core & 3 & 9 & 12 \\
\hline Single platform core & 2 & 6 & 8 \\
\hline "Radial" core & - & 2 & 2 \\
\hline Assayed cobble & 2 & 1 & 3 \\
\hline Hammerstone & 66 & 65 & 131 \\
\hline Grindstone & 1 & - & 1 \\
\hline Unidentified & 102 & - & 102 \\
\hline Other & 6 & 7 & 13 \\
\hline Total & 69,288 & 14,570 & 83,858 \\
\hline
\end{tabular}

* Microdebitage count not added to total number of artifacts analyzed.

Reduction sequence analysis indicates there were at least three separate methods employed for making axes within Feature 1: Method 1, Method 2, and Method 3 (see Figs. 9-12).

1. Method 1 ("block-based") involved the reduction of large unmodified blocks of dolerite into bifacially flaked axe blanks;

2. Method 2 ("slab-based") involved the reduction of relatively thin flat slabs and tabular pieces of dolerite into bifacially flaked axe blanks;

3. Method 3 ("flake-based") involved the reduction of amorphous flakes and nonflake debitage into both unifacially and bifacially retouched axe blanks.

Each of these axe reduction methods are described as follows:

\section{Method 1}

Method 1 was the most complex axe manufacturing method within the reduction system (Fig. 9). Knapping axes in this manner involved four sequential stages of reduction, some of which were conducted in spatially segregated locales (Table 3). Each of these stages is described below.

Stage 1 - The first stage of reduction, raw material procurement, required access to large unmodified blocks of high-quality, internally homogenous dolerite. Such blocks were (and still are) available only from the nearby quarried dolerite outcrops and would most likely have required the excavation of mining pits into the subterranean rock mass. While internally homogenous blocks of stone can be 

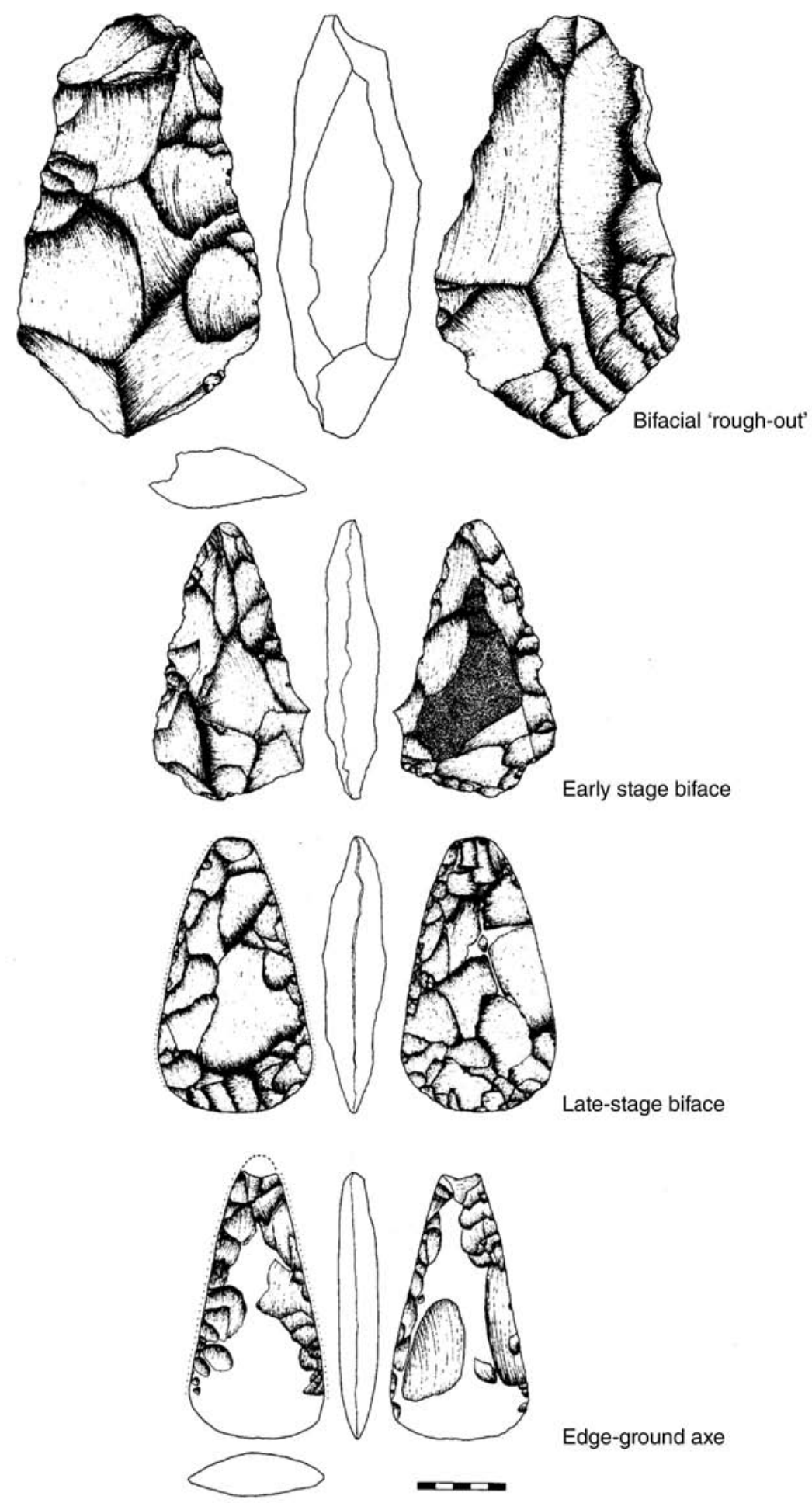

Fig. 9. Idealized reduction sequence model (using artifactual specimens from Area A) indicating sequential stages in the manufacture of Method 1 dolerite axes. Scale is in centimeters. 
Table 3. Axe Reduction Methods Recorded at Hiregudda

\begin{tabular}{|c|c|c|}
\hline METHOD I & METHOD 2 & METHOD 3 \\
\hline $\begin{array}{l}\text { Stage 1: Raw material procurement } \\
\text { Stage 2: Early reduction or "edging" } \\
\text { of raw stone blocks into large } \\
\text { bifacial "rough-outs" } \\
\text { Stage } 3 a \text { : Bifacial thinning and } \\
\text { contouring } \\
\text { Stage } 3 b \text { : Bifacial trimming and } \\
\text { shaping } \\
\text { Stage 4: Pecking and/or grinding }\end{array}$ & $\begin{array}{l}\text { Stage 1: Raw material } \\
\text { procurement } \\
\text { Stage 2: Bifacial } \\
\text { reduction } \\
\text { Stage 3: Pecking } \\
\text { and/or grinding }\end{array}$ & $\begin{array}{l}\text { Stage 1: Procurement of } \\
\quad \text { flake or nonflake debitage } \\
\text { Stage 2: Bifacial or unifacial } \\
\quad \text { retouch } \\
\text { Stage 3: Grinding }\end{array}$ \\
\hline
\end{tabular}

found that measure over $300-400 \mathrm{~mm}$ in maximum dimensions, these are relatively infrequent and are often full of internal fracture planes. The Neolithic stoneworkers presumably had to dig extensively to produce adequate supplies of these large stone packages.

Stage 2 - Initial "edging" of the stone blocks was by direct freehand percussion, apparently using pieces of dolerite as hammerstones. Stage 2 seems to have been conducted both at the quarry sources and in Feature 1 and adjacent locales in Area A. More detailed analysis may lead to the discrimination of discrete substages of early reduction that were conducted in more specific spatial localities.

The general aim of the early reduction phase was to impose a biface center plane on angular blocks of stone (see Andrefsky 1998; Moore 2003b; Whittaker 1994 for discussions of bifacial reduction techniques). This required significant reduction of core mass and the removal of any right-angled edges and other major irregularities in cross-section. At least two different early reduction strategies were recorded: "unifacial beveling" and "alternate flaking," sometimes on the same core. Unifacial beveling involved the removal of a series of unifacial flakes from one side of the block using a single platform surface. The block was then rotated and the negative scars from the previous removals used as platform surfaces for subsequent unifacial removals from the opposite face. Alternate flaking involved the removal of a flake from one side of the block, after which the block was rotated and the resulting negative flake scar used as a platform for the removal of flakes from the opposite face.

The morphology and dimensions of early reduction flakes appear to have varied according to the specific platform morphology and configuration of core mass being removed. Most had relatively large cortical, single or multifaceted platforms, prominent bulbs of force, and low dorsal-flake scar counts. A particularly diagnostic flake type produced during the early reduction "edging" stage consisted of "ridge-running" flakes. These were bladelike cortical flakes removed down the right-angled corners of the angular stone blocks, presumably to create a platform surface for subsequent flake removals.

"Edged blanks" made from large stone blocks were transported from the quarried outcrops to Area A at various stages of reduction. Mostly, however, it seems they were removed from the quarries as bifacial "rough-outs" ready for thinning and contouring (see Stage 3a below). A few early reduction flakes measuring up to $150-200 \mathrm{~mm}$ in length were recorded among quarry debris at the Lower Quarry. This would seem to indicate that large blocks were primarily worked at 
Table 4. Dorsal Cortex Amount for Early Reduction Flakes from Two Stratigraphic Contexts in Trench i, Area A

\begin{tabular}{lcccccc}
\hline & & & $N$ with & FUll & PARtial & PERCENT \\
CONTEXT & Flake TYPE & $N$ & CORTEX & CORTEX & CORTEX & With CORTEX \\
\hline Trench 1/3000 & Early reduction & 1455 & 172 & 3 & $169(<50 \%)$ & $11.75 \%$ \\
Trench 1/3002 & Early reduction & 1145 & 83 & 0 & $83(<50 \%)$ & $7.24 \%$ \\
\hline
\end{tabular}

the raw material source. Moreover, the mean length of a sample of 50 of the largest early reduction flakes recorded in five separate stratigraphic contexts in Feature 1 measured $64.54 \mathrm{~mm}$ (61.82 $\mathrm{mm}$ in width, $18.28 \mathrm{~mm}$ in thickness). The relatively low numbers of early reduction and biface thinning flakes with remnant portions of cortex recorded in Area A also suggests that the transportation of unmodified or only partially modified blocks of dolerite from the quarries was relatively uncommon (Table 4).

Stage $3 a$ - The next stage of reduction involved the invasive thinning and contouring of these bifacial "rough-outs." This seems to have taken place mostly within Feature 1 and adjacent areas, although a number of biface thinning flakes were noted among the quarrying debris at the Lower Quarry.

The early bifacial thinning stage was probably conducted using soft-hammer percussors of antler, bone, or hardwood, although hard stone hammers may also have been used (see Pelcin 1997). The aim seems to have been to remove any surface irregularities and/or areas of high topography on the rough-out, resulting in reduced thickness in cross section and a continuous bifacial platform edge extending around the periphery of the blank. Using these carefully prepared bifacial edges as platforms, invasive thinning flakes were removed from both margins of the blank. Reduction was predominately by the alternate flaking technique. As discussed below, bifacial thinning and contouring involved the use of various platform preparation techniques and strategies for recovering from knapping error. The outcome of the early bifacial thinning and contouring stage was an early stage bifacial axe blank with relatively smooth surfaces and a more or less symmetrical biconvex cross section.

Early stage biface thinning flakes were relatively diagnostic. They generally (but not always) featured small "lipped" platforms resulting from bending initiations, acute external platform angles, pronounced curvature in cross section, and evidence for careful platform preparation (see below). Most of these flakes were rather flat and wide (i.e., "expanding") in plan view and exhibited complex arrangements of overlapping dorsal flake scars (see especially Andrefsky 1998; Whittaker 1994).

Stage $3 b$ - Examination of Method 1 blanks suggests that the final bifacial reduction step entailed the detachment of a series of small noninvasive late-stage bifacial thinning flakes from around the periphery of the invasively flaked axe blank. This had the effect of trimming and shaping the bifacial blank into a preform ready for grinding. Formed object analysis suggests that Stage $3 \mathrm{~b}$ should result in bifacial thinning flakes that are generally distinguishable from early stage bifacial thinning flakes due to their small size. However, the subdivision of Stage 3 was justified on the basis that it was somewhat difficult to distinguish trimming and 
shaping flakes from small early stage bifacial thinning flakes. Detailed debitage analysis would be needed to tease out specific distinctions between the types. The lack of clear morphological boundaries between early and late-stage bifacial flakes could also suggest that there was a continuum rather that a strict separation between these production stages (e.g., Bleed 2002).

Stage 4 - Finally, these carefully manufactured bifacial axe blanks were then pecked and/or ground. A number of hammerstones were found in the assemblage that could provide evidence for the pecking process, though this was mostly inferred by the recovery of some partially pecked late-stage axe blanks. As mentioned above, axe grinding took place on a large granite quern located inside Feature 1 and apparently reused for this purpose (see Fig. 6; see also Fig. 4). Several other axe-grinding features have also been recorded within close proximity to this structure. Axe grinding seems to have been confined mostly to creating a functional cutting edge and to grinding flat opposing faces of the axe along the length axis, in some cases extending all the way to the butt (see Allchin 1957 for discussion). Grinding along the lateral margins of axes was also recorded (probably a modification for hafting), but complete grinding of axes was rare.

Platform Preparation and Error Recovery - Before moving on to a description of the other axe reduction methods, it is worthwhile to briefly discuss some of the knapping strategies and techniques employed during Method 1 bifacial reduction. In particular, it is important to mention two of the most important aspects of the bifacial thinning stages: (1) techniques involved in platform preparation and (2) recovery from knapping error.

Platform preparation has the effect of stabilizing the intended striking platform by removing any small irregularities or weak points that might disrupt flake initiation and propagation (see Whittaker 1994:98-104). Examination of debitage suggests that careful platform preparation took place mostly during the early stage bifacial thinning and contouring (Stage 3a) of Method 1 blanks. Platform preparation techniques recorded included (1) lateral grinding, (2) overhang removal by percussion oriented down the core face, and (3) lateral grinding over overhang removal. The lateral grinding technique, the most common platform preparation technique recorded, involved lightly or heavily grinding the platform edge on an angle roughly $90^{\circ}$ to the flake percussion axis. This resulted in a platform edge with a "rolled" appearance and was probably conducted using some form of abrasive material such as a handheld granite grindstone (objects matching this description were recovered from deposits in Feature 1). The overhang removal technique involved the removal of platform overhang by gentle freehand percussion oriented in the same direction as the flake percussion axis, probably with a hammerstone or other percussor. And finally, lateral grinding over overhang removal entailed a combination of the above two platform preparation techniques. The use of these three platform preparation techniques by Method 1 knappers demonstrates both the complex organization of the bifacial reduction sequence and the concern taken by individual knappers when attempting to detach biface thinning flakes.

Formed object analysis and comparative examination of debitage also suggests that Stage 2 and Stage 3a knappers employed a range of techniques for overcoming problems encountered during the early reduction and bifacial thinning and 
contouring process. Such problems were usually caused by knapping error. For example, several different techniques for removing "stacks" (protuberances caused by step and/or hinge termination flakes) on the bifacial platform surface were recorded. One approach involved simply setting up a new platform a suitable distance (c. $>5 \mathrm{~mm}$ ) in from the damaged platform edge and removing the stack by direct freehand percussion. Several error recovery flakes of this type were identified in the assemblage. Another option for the removal of stacks involved setting up a platform on the opposite side of the damaged platform edge and removing the stack from there by direct freehand percussion. Sometimes both of these techniques for "sneaking up" on an area of high mass were employed on bifaces. For example, one early stage bifacial axe blank was noted that featured an area of high mass on one face in the approximate center of the biface. The knapper evidently tried unsuccessfully to remove this protuberance by attacking it from two different directions. These attempts failed, however, and the force required to remove the last flake (and/or failure to support the biface properly) probably resulted in the biface snapping due to an end-shock fracture.

Another interesting error recovery technique recorded in the assemblage involved flaking directly into the stack itself, using protuberances such as the distal ends of step termination flake scars as platforms.

Finally, a nonflaking technique noted for the removal of stacks on bifaces involved reducing these areas of high mass by pecking and/or grinding. Sometimes this latter technique was combined with those techniques mentioned above. Indeed, one specimen evidenced an attempt to remove a stack by directly flaking it, using the distal end of a stepped termination flake scar on the stack as a platform surface. After this failed, a short-lived attempt was made to grind away a similar topographical irregularity on the opposite face.

\section{Method 2}

Method 2 involved a relatively more straightforward sequence of bifacial axe reduction (Fig. 10). This method seems to have entailed the preferential selection of flat slabs and tabular pieces of dolerite that were naturally shaped to the approximate thickness of an axe blank (c. 20-30 mm). Stone packages for Method 2 reduction would have been readily available in the local lithic terrain, and only minimal investment in mining activities would have been required to obtain significant quantities of such stone packages. The rock mass at the local quarried dolerite outcrops weathers naturally along internal cleavage planes into innumerable flat slabs, plates, and tabular pieces of dolerite suited to Method 2 reduction. Local colluvial sources and other secondary geological deposits were probably also targeted for slabs and flat cobbles of dolerite.

Reduction of slabs and tabular pieces varied according to the specific morphology of the stone package at hand. In general, however, Method 2 axes were manufactured by the alternate removal of relatively noninvasive flakes from around the perimeter of the stone piece. The use of noninvasive bifacial flaking techniques was probably a symptom of the natural thinness of the original stone packages, obviating the need for intensive thinning and contouring of blanks. This particular reduction method did, however, tend to produce rather characteristic axe blanks, recognizable by the presence of isolated patches of cortex on op- 

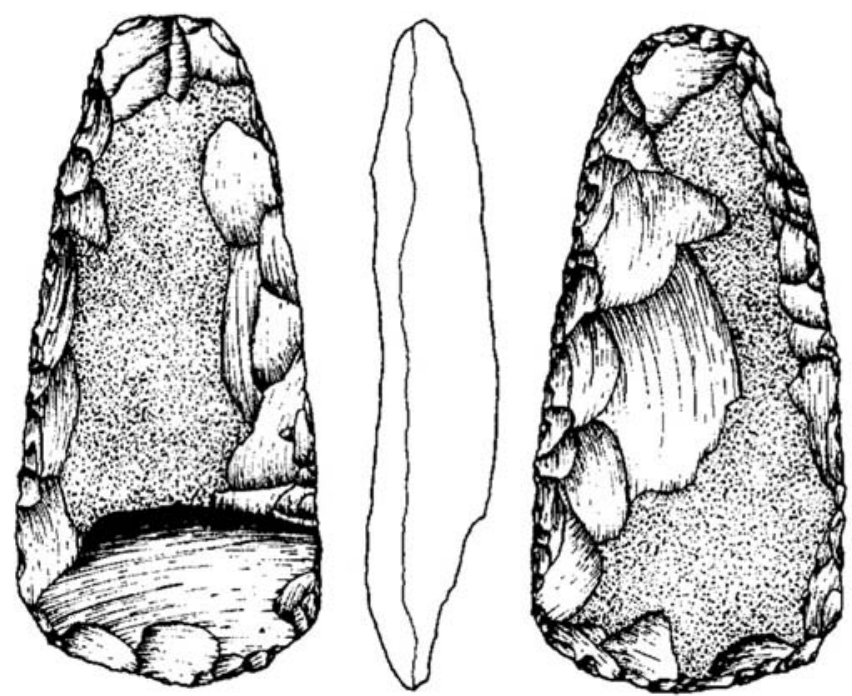

A
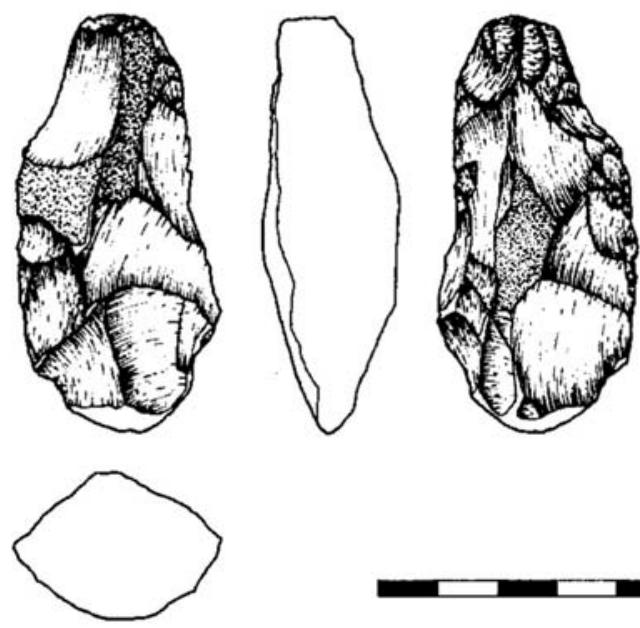

B

Fig. 10. Ground (B) and unground (A) Method 2 dolerite axes recovered from Feature 1, Area A. Both have been made on flat cortical slabs or tabular pieces of dolerite. Scale is in centimeters.

posite sides of the biface. Some Method 2 edge-ground axes suggest attempts on the part of stoneworkers to remove these remnant patches of cortex prior to the grinding process, generally by pecking. Most often, however, they were simply left on the ground tool. It is possible in principle that some Method 1 and Method 2 axe blanks might have become integrated during formed object analysis; for example, in cases where Method 2 knappers managed to remove most or all of the cortex from flat slabs or tabular pieces of dolerite. In general, however, the natural thinness of the slabs and tablets of dolerite available as weathered stone 
packages in the local dolerite sources seems to correspond with the mean thickness of axe blanks and axes in the assemblage (c. $20-30 \mathrm{~mm}$ ). This suggests that Method 2 knappers may not have been concerned with substantially reducing the thickness of the initial stone packages but rather with modifying the length and width of axes. In principle, therefore, Method 1 and Method 2 axe blanks should be distinguishable.

\section{Method 3}

Method 3 axe reduction - by far the most straightforward method recordedinvolved the expedient retouch of small irregularly shaped pieces of flake and nonflake debitage, including random pieces of angular shatter, into both unifacially and bifacially retouched axe blanks (Figs. 11 and 12). Retouch on Method 3 blanks was almost always noninvasive, limited to the removal of small retouching flakes from around the periphery of the flake blank. Edge grinding was usually minimal and confined to the formation of a functional working edge only. Most Method 3 axes measured less than $100 \mathrm{~mm}$ in maximum dimension.

There seems to have been no set pattern or preference for the types of debitage chosen for Method 3 axe manufacture. There is some indication that fortuitously teardrop-shaped flakes were preferentially selected for reduction in this manner. It also seems probable that early reduction flakes produced during the initial roughing-out of bifaces in Method 1 (see above) were manufactured into Method 3 axes. Overall, however, it seems that almost any randomly produced dolerite flake or piece of debitage could be expediently retouched and ground for use as an axe. One edge-ground "axe" recovered from the early occupation phase in Feature 1 even consisted of a tiny piece of angular shatter that had been very minimally retouched on one portion of the artifact and then ground (see Fig. 13c).

During analysis, Method 3 axes were identified by the preservation of the point of applied force-or the platform surface, bulb of percussion with ring crack, erraillure scars, radiating compression rings, and other diagnostic features (see Cotterell and Kamminga 1987)—on the axe blank. In cases where flake blank axes had been reduced to the extent that these features were absent, it was often difficult to identify the precise orientation of the flake percussion axis in the formed object. Nonetheless, the presence of a dorsal and ventral surface on either face of the axe blank, as well as percussion ripples, radial fissures, linear striae, and other diagnostic characteristics of flake initiation and propagation, were often discernable.

\section{ORGANIZATION AND CHRONOLOGY OF AXE PRODUCTION AND EXCHANGE}

As alluded to above, Method 1 block-based axe reduction would have required access to large blocks of dolerite, some of which measured over $300-400 \mathrm{~mm}$ in maximum dimensions. By contrast, Method 2 slab-based axe reduction involved the reduction of relatively thin and flat slabs or tabular pieces of dolerite, items readily available in the local lithic terrane. Finally, Method 3 flake-based axe reduction involved the reduction of amorphous pieces of dolerite flake or nonflake debitage produced during unstructured dolerite core reduction methods (i.e., single-platform, multiple-platform, radial core reduction) and/or Method 1 stages 


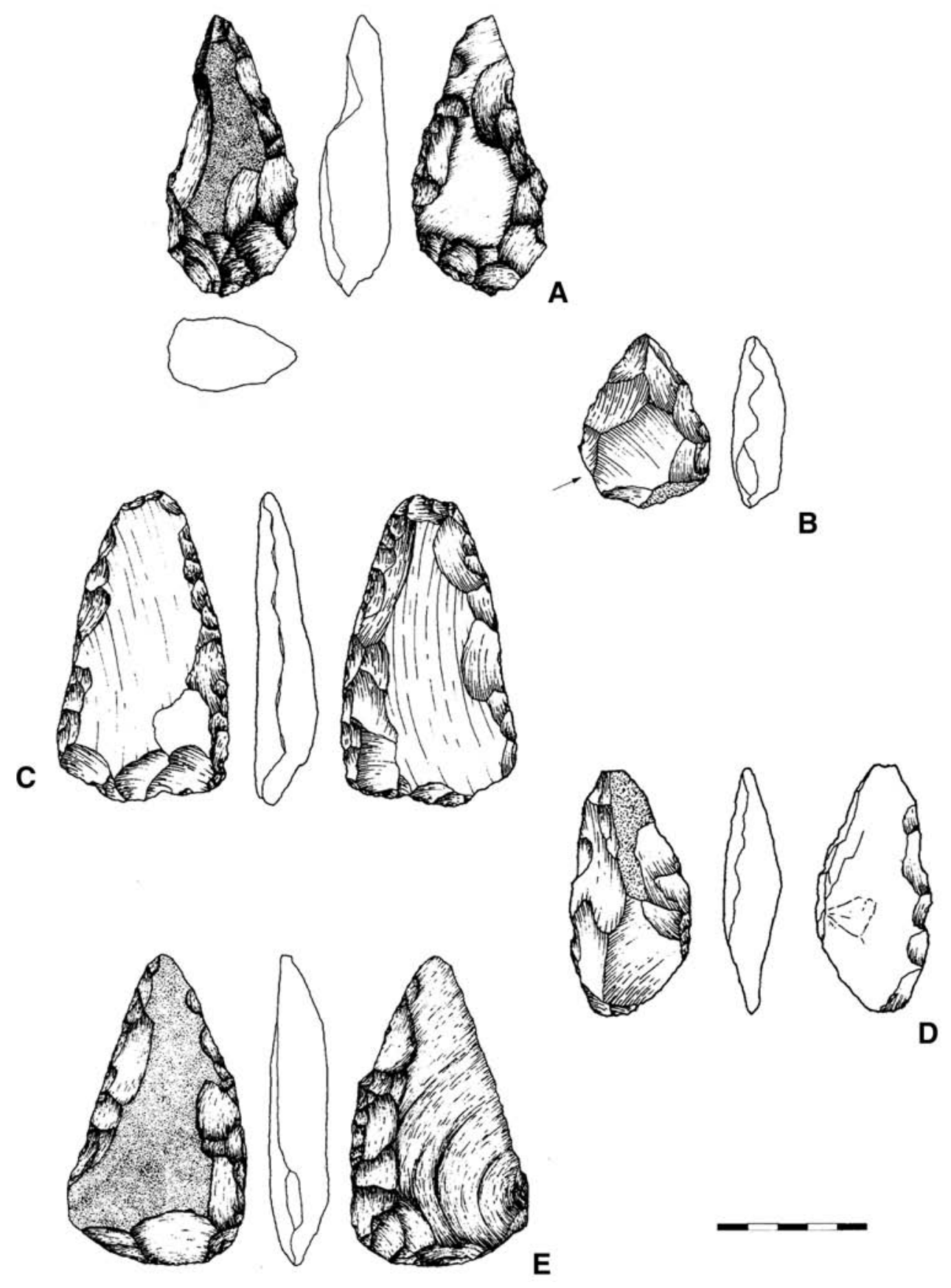

Fig. 11. Method 3 dolerite axe blanks from Area A. All have been made on amorphous flakes or pieces of nonflake debitage. Scale is in centimeters. 

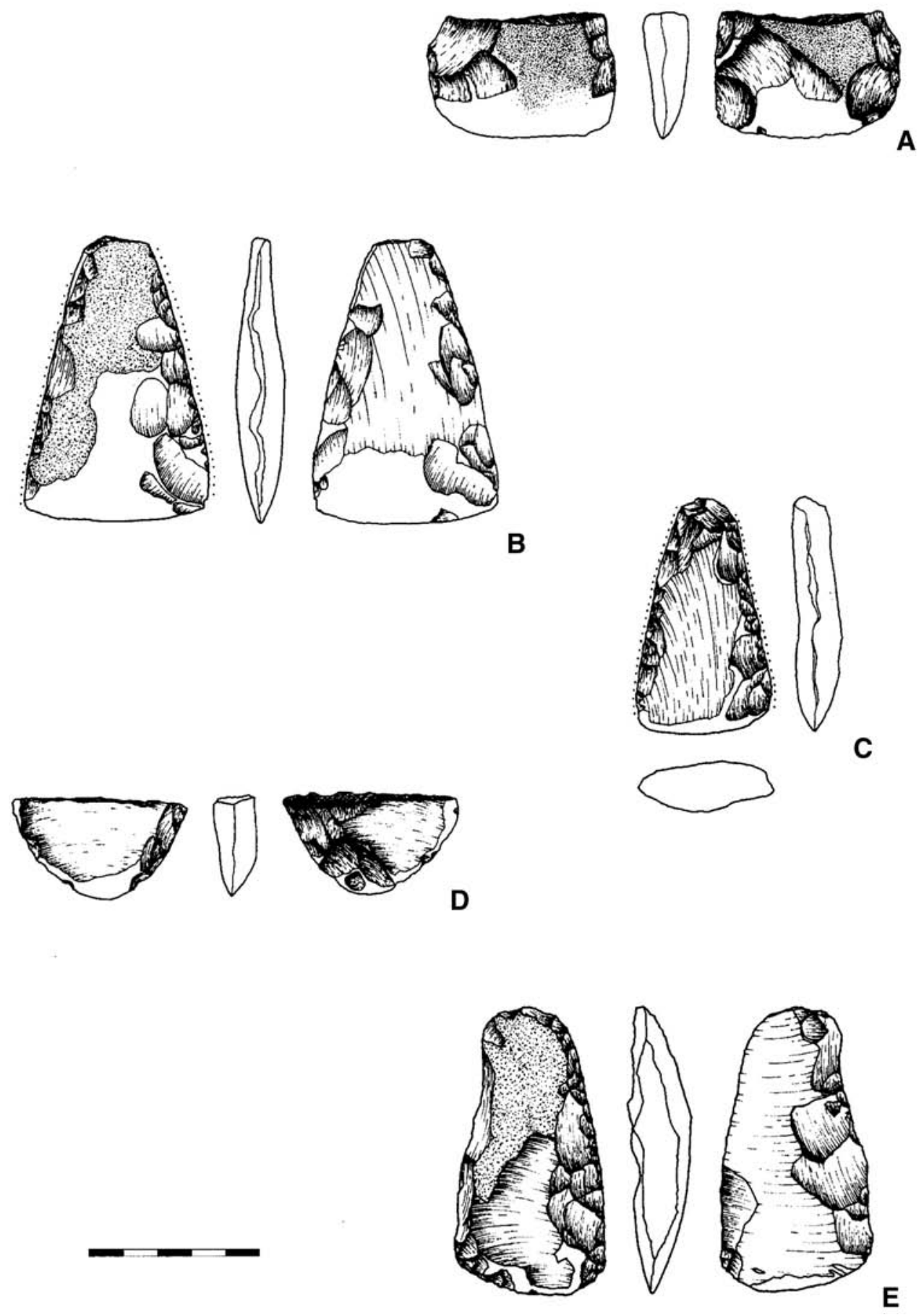

Fig. 12. Edge-ground Method 3 dolerite axes from Area A. Scale is in centimeters. 

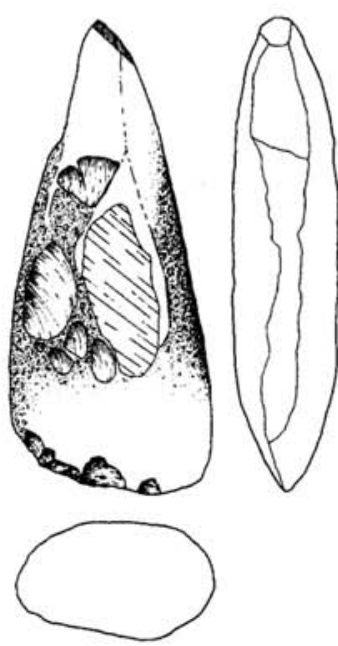

B

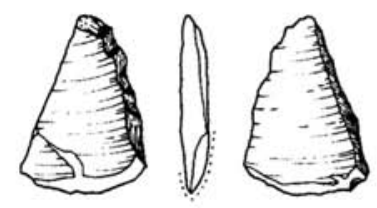

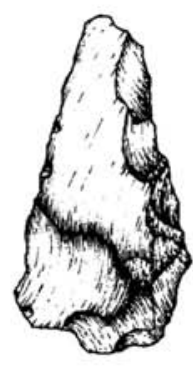

A

C
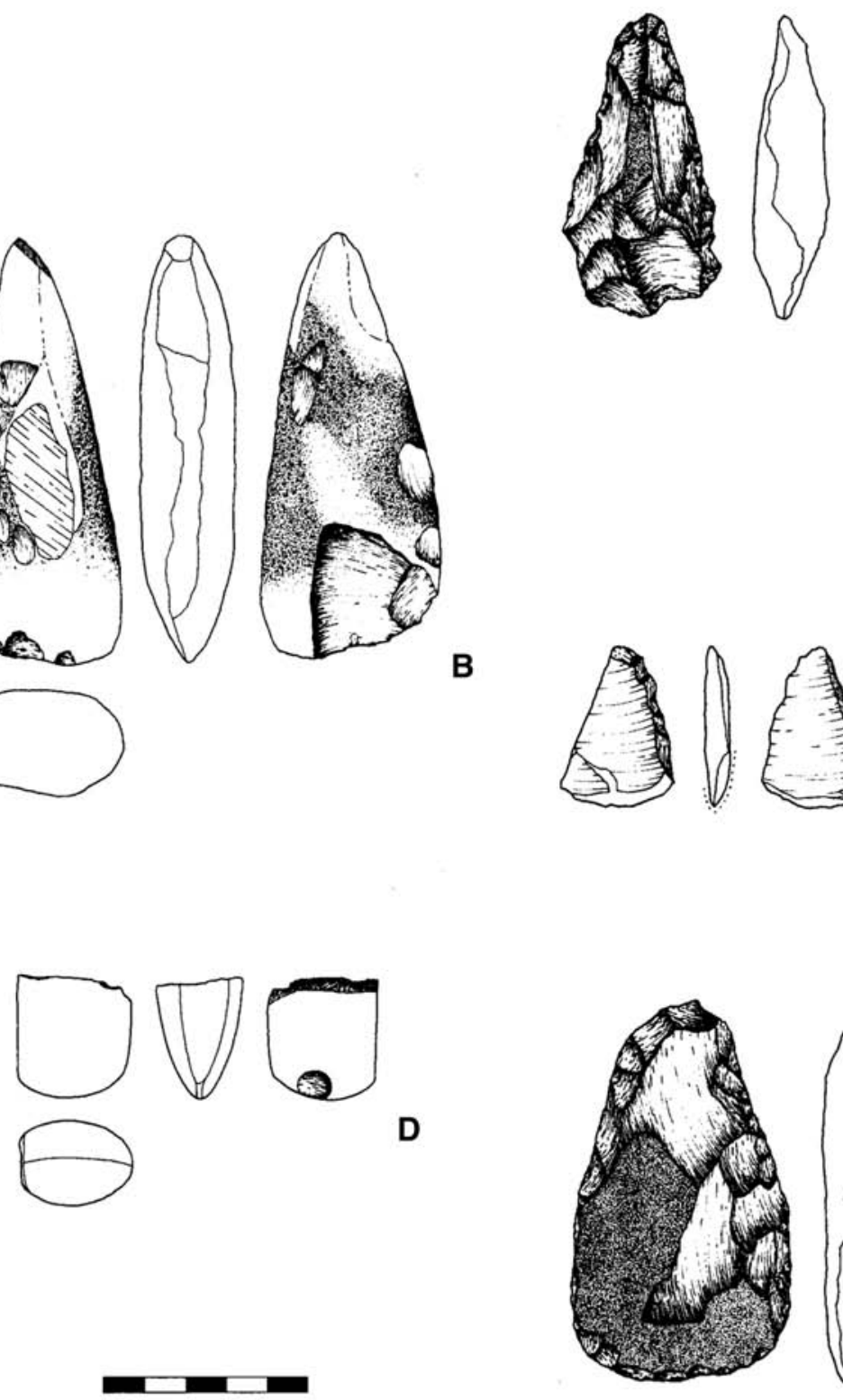

D
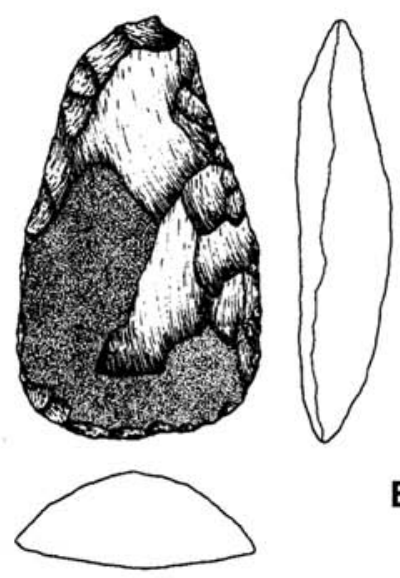

E

Fig. 13. Dolerite axes and axe blanks recorded in early occupation phase stratigraphic layers and contemporaneous horizons in Feature 1, Area A and nearby Sanganakallu-Kupgal sites. The unusual edge-ground axe in drawing D was recovered from the nearby Sannarachammagudda ashmound. Scale is in centimeters. 
of bifacial reduction. All of these methods in principle required access to quarried dolerite from the local trap dykes at Hiregudda. However, due to the relative infrequency of large internally homogenous blocks of stone in the weathered dolerite outcrops, Method 1 would most likely have required much larger scale and more intensive quarrying operations than would have been necessary for Method 2 and, indeed, Method 3. In addition, Method 1 bifacial axes were generally much larger and more finely worked specimens than Method 2 and Method 3 axes. The sheer amount of time and skill that went into the knapping of a Method 1 axe compared to the other varieties is also significant. These carefully flaked bifaces are impressive examples of flintknapping, and it is difficult to avoid the conclusion that such finely made axes would have had important socioeconomic and/or aesthetic values in Southern Neolithic society.

Given the varying technical and logistical requirements of their manufacture, as well as the differences in their final forms, it seems possible that axes produced according to these three separate reduction methods operated in quite different functional and socioeconomic contexts during the Neolithic period. The most obvious (but admittedly simplistic) possibility is that the complex block-based bifacial axes produced by Method 1 knappers were intended primarily as prestige items for stone exchange networks. As noted, the manufacture of these large invasively flaked symmetrical axes required a complex sequence of bifacial reduction. What's more, these are impressive, aesthetically appealing stone tools, and the high level of technological standardization and the complexity of production processes seem to hint at specialist contexts of use and distribution (i.e., longdistance exchange) (see Berg 2004; Eerkens and Bettinger 2001; Gibson 1982; Kenoyer et al. 1991; Peregrine 1991; Pigeot 1990; Shafer and Hester 1991; VanPool and Leonard 2002). The more expediently manufactured Method 2 and Method 3 axes, on the other hand, which by comparison would have taken much less time, effort, and skill to produce, may have been manufactured more with local use in mind (e.g., Pétrequin et al. 1998). These latter varieties might have functioned as the more domestic types of axes produced not so much as prestige items and/or for exchange but as the everyday work axes of Neolithic pastoral communities (although this is not to say that they did not also possess sociosymbolic values or meanings in Neolithic society).

Extensive (though still unsystematic) archaeological survey has indicated that there is a proliferation of surface finds of Method 2 and, especially, Method 3 blanks and edge-ground axes in and around Hiregudda and elsewhere within the Bellary District. This implies a general pattern in which Method 1 axes moved away from Hiregudda, whereas Method 2 and Method 3 axes were mostly used and disposed of locally. Of course, we cannot discount the effect of collector bias in this process; British antiquarians engaged in the "pleasures of celt hunting" (Subbarao 1948:5) were especially prolific in the Bellary District (Allchin 1957). However, it is significant to note that in situ axe assemblages recovered during excavations revealed broadly similar trends. Thus the manufacture of Method 1 axes seems to hint that stone production at Hiregudda was concerned with more than the simple provisioning of work tools within the immediate community (see Edmonds 1990).

In terms of the social organization of axe production, it also seems likely that the manufacture of Method 1 axes required the involvement of highly skilled and 
experienced knappers (e.g., Roux et al. 1995). The degree of technological complexity documented in Method 1 seems especially to hint at the existence of partor full-time knapping specialists, individuals with particularly well-developed knapping skills and knowledge. We might expect such levels of organization to occur within the context of senior/apprentice stoneworking systems similar to those that have been documented ethnographically in Indonesian Papua, formerly Irian Jaya (e.g., Hampton 1999; Pétrequin and Pétrequin 1993; Pétrequin et al. 1998; Stout 2002; Toth et al. 1992). Among traditional Langda adze makers, the production of adzes was (is) conducted by small groups of interrelated senior and apprentice stoneworkers, all males (Stout 2002). Because of the great social and economic value of this skill, master knappers were inclined to teach the craft only to their direct sons and nephews and only to those apprentices who demonstrated a high level of seriousness and commitment. As Stout recorded, such apprenticeships could last five years or more (702). Learning how to make large bifacial adzes not dissimilar to Method 1 axes from Hiregudda could reputedly take a period of up to ten years apprenticeship, and we consider it not unlikely that similarly long periods of training and apprenticeship may have been involved in Method 1 axe reduction. In Indonesian Papua, specialist adze-making organizations, such as might operate from spatially segregated workshops, seem to have produced large bifacial adzes primarily for ceremonial exchange (Pétrequin et al. 1998).

Emerging radiometric evidence from the Sanganakallu-Kupgal sites provides provisional support for a similar scenario at Neolithic Hiregudda. The recently established chronological framework for Neolithic occupation at Hiregudda has been discussed in detail elsewhere (Fuller et al. forthcoming). Briefly, however, radiocarbon dates from stratified charcoal and seeds indicate two separate phases of occupation of varying scales of intensity and organization in Area A. In Feature 1 and adjacent locales in Area A, what appears to have been a domestic-oriented early phase of habitation, during which dolerite axes were manufactured on a more limited scale, terminated at around 3500 B.P. This was followed by a period of abandonment lasting several hundred years. The dwelling and associated hilltop settlement was reoccupied again around the thirteenth or fourteenth millennium B.C., and it is during this Late Neolithic/Early Megalithic (Iron Age) transition phase that archaeological deposits provide evidence for an unprecedented intensification in the production of bifacial dolerite stone axes. This is also the first time that we see direct evidence in the lithic assemblage for the manufacture of complex block-based Method 1 axes alongside simpler Method 2 and Method 3 axes. Prior to this time, Method 1 axe materials appear to be rare or absent altogether in the assemblage.

Thus a general picture is emerging in which Neolithic stoneworkers in Feature 1 and Area A may have manufactured the simpler or more expedient types of axes during the earlier phase of domestic habitation, perhaps for use as local work tools or for limited distribution (see Fig. 13). However, the more complex, blockbased axe types seem to have been made primarily during the Late Neolithic/ Early Megalithic transition phase, and it is tempting to suggest that these objects were integrated into long-distance exchange networks in South India. Large-scale quarrying of the dolerite outcrops at Hiregudda may not have taken place until this intensive axe production phase. 
We must be careful about taking this scenario too far, given the current lack of archaeological data and the preliminary stages of our technological investigations. It does seem relevant to note, however, that this was a time when small amounts of decorative copper and gold-present in low frequencies at other Southern Neolithic sites (see Korisettar et al. 2001; Wheeler 1948) - were first appearing as exotic long-distance trade items in the Sanganakallu-Kupgal region. There are examples from the archaeological record of stone tool production systems becoming more complex in areas that overlapped with metal-producing communities and/or where tools and objects of metal were becoming available through exchange networks; for example, the elaborate flint "skeuomorphs" of bronze daggers in Late Neolithic Scandinavia (Lubbock 1869; Stafford 2003; see also Rosen 1997 for a Near Eastern perspective). One hypothesis we are therefore exploring is that the infiltration of highly valued and probably symbolically laden metal items during the Late Neolithic period led to a major increase in the production of dolerite axes for exchange in South India, including elaborately manufactured and possibly status-linked Method 1 forms.

\section{CONCLUSION}

Our current archaeological understanding of the technological organization of axe production during the Neolithic period in South India is at a very early stage of development. Many issues remain to be addressed. Further refinement and testing of the axe reduction methods proposed in this paper are necessary. Our reconstruction of the technology is at a very preliminary and necessarily coarsegrained stage, and working hypotheses presented here require more sustained testing, research, and quantitative analyses.

A much more comprehensive understanding of the temporality of axe manufacture and exchange in South India is also needed. First appearances suggest that axe production and exchange extended over a significant period of time at Hiregudda. In particular, the prolific concentration of surface and subsurface dolerite debitage and the scale of the (palimpsest) quarries seem to indicate that an extraordinary level of industrial activity took place at the site. However, other monumental landscape features in the Sanganakallu-Kupgal study area-notably the immense Neolithic ashmounds (accumulations of burned and vitrified cattle dung; see Allchin 1963) — are being shown to have had a much shorter chronology than previously expected (Fuller et al. forthcoming). Our data suggest the possibility of a brief but very intensive Late Neolithic phase of axe-production activity, and it may be that the formation of these impressive lithic sites took place over relatively short time frames. Whether we are talking about a matter of years, decades, centuries, or longer is not known, however. To resolve this problem, much more detailed archaeological investigation is clearly needed-particularly estimates of production rates and the excavation and radiocarbon dating of dolerite mining pits.

It is also of importance that we attempt to add a regional-scale perspective to the emerging picture of site-level axe production and exchange in South India. Our own provisional insight into chronological developments at the key quarrying/production site of Hiregudda highlights the potential value of expanding the current perspective to incorporate what was happening at contemporaneous lithic 


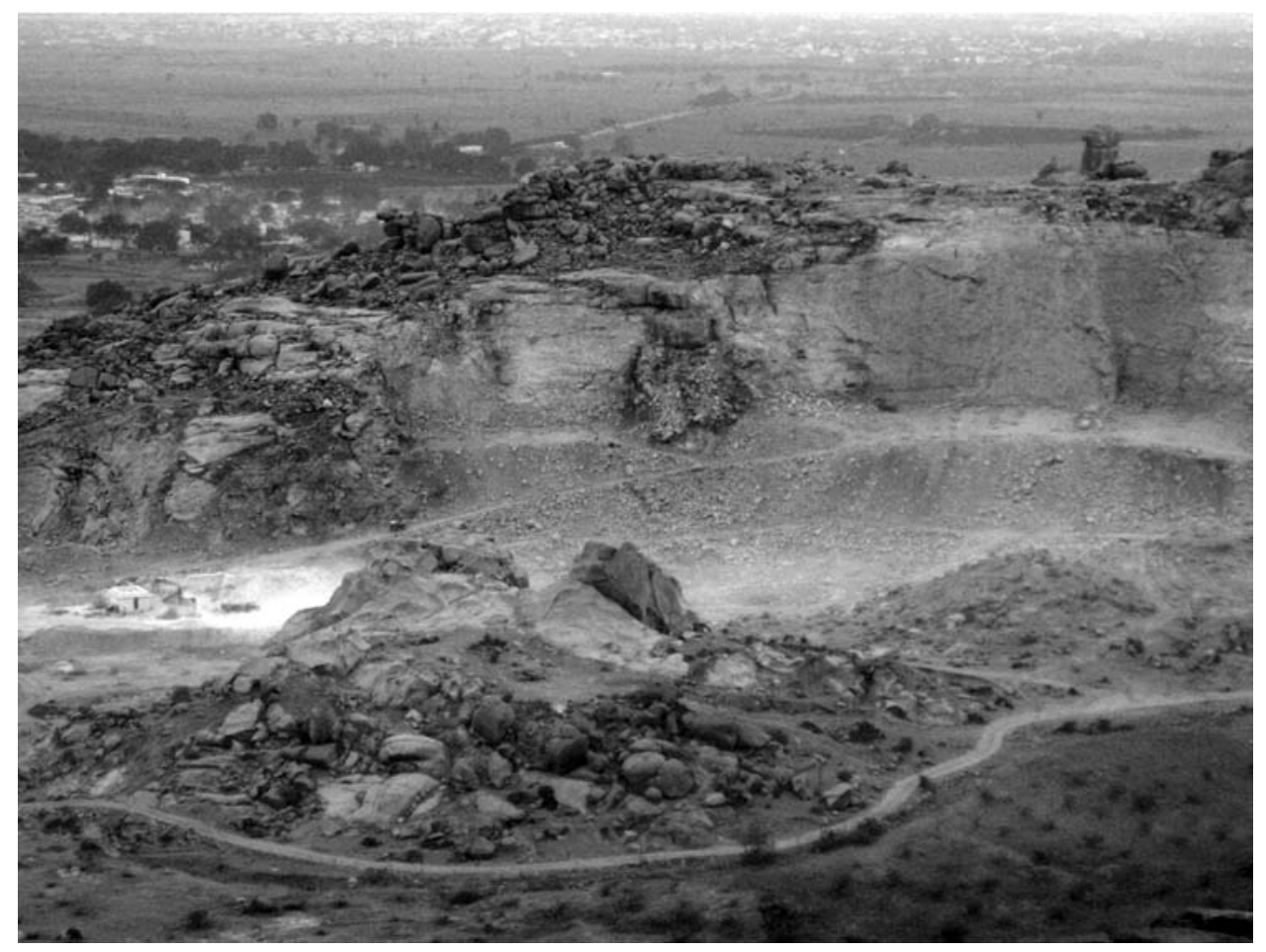

Fig. 14. Industrial-scale granite quarrying and mining activities threatening Neolithic sites at Sanganakallu-Kupgal.

production locales (especially dolerite trap dykes) elsewhere in the Central Deccan. To date, there have been no systematic petrographic studies carried out on Neolithic stone axes in South India; earlier studies on geographical patterns of the distribution and movement of stone axes in South India have been largely impressionistic in nature (e.g., Worman 1949). If we are to understand the role of localized axe quarrying and production organizations in the wider Neolithic exchange systems, raw petrological data is essential.

With this last point, we would like to further reiterate the urgent need for all of this research. Robert Bruce Foote described the Neolithic sites of Hiregudda as pristine in the early 1900s (1916). However, it is a very different story today, when most if not all of these rich and varied sites are currently under serious threat from commercial granite mining and other modern activities (Boivin et al. 2005) (Fig. 14). Industrial mining has already significantly impacted the recently discovered Lower Quarry situated at the southeast foot of Hiregudda, and the steady demolition of the quarry continues today. By the time more inclusive models for the interpretation of axe production and exchange networks in Neolithic South India are available, there may be very little (if any) contextual archaeology left to study. Given these circumstances, we would like to urge both local and international archaeologists to work together to ensure the proper recording of these South Indian prehistoric sites and, where possible, protect them from complete destruction. 


\section{ACKNOWLEDGEMENTS}

The findings discussed in this article would not have been possible without the important contributions made by many other members of the Sanganakallu-Kupgal team, in particular E. Asouti, B. Janardhana, F. Cole, N. Drake, H. M. Anitha, H. Lewis, L. Lloyd-Smith, K. Malagyannavar, P. Masser, S. Meece, M. Petraglia, P. Prasanna, S. Pujar, N. Rees, Ramadas, D. Robinson, and C. Shipton. This research has been funded by the British Academy, as well as the McDonald Institute for Archaeological Research, the Arts and Humanities Research Board, and Karnatak University. Brumm would like to thank Mark Moore from the University of New England in Armidale for insightful conversations about stone technology and comments on earlier drafts of this essay.

\section{REFERENCES}

Adams, W. Y., And E. W. Adams

1991 Archaeological Typology and Practical Reality: A Dialectical Approach to Artifact Classification and Sorting. Cambridge: Cambridge University Press.

Allchin, F. R.

1957 The ground stone industry of the North Karnataka region. Bulletin for the School of Oriental and African Studies 19(2):321-335.

1960 Piklihal Excavations. Andhra Pradesh Government Archaeological Series 1. Hyderabad: Government of Andhra Pradesh.

1962 The Neolithic stone industry of the Santal Parganas. Bulletin for the School of Oriental and African Studies 25(1/3):306-330.

1963 Neolithic Cattle-Keepers of South India: A Study of the Deccan Ashmounds. Cambridge: Cambridge University Press.

ANDREFSKY, W. JR.

1998 Lithics: Macroscopic Approaches to Analysis. Cambridge: Cambridge University Press.

ANSARI, Z. D.

1988 Blade industry, in Excavations at Inamgaon, vol. 1, part 2:509-526, ed. M. K. Dhavalikar, H. D. Sankalia, and Z. D. Ansari. Pune, India: Deccan College.

BERG, I.

2004 The meanings of standardisation: Conical cups in the Late Bronze Age Aegean. Antiquity $78: 74-85$.

Bisson, M. S.

2000 Nineteenth century tools for twenty-first century archaeology? Why the Middle Paleolithic typology of François Bordes must be replaced. Journal of Archaeological Method and Theory $7(1): 1-48$.

BLEED, P.

1991 Operations research and archaeology. American Antiquity 56(1): 19-35

2001 Trees or chains, links or branches: Conceptual alternatives for consideration of stone tool production and other sequential activities. Journal of Archaeological Method and Theory $8(1): 101-127$.

2002 Obviously sequential, but continuous or staged? Refits and cognition in three Late Paleolithic assemblages from Japan. Journal of Anthropological Archaeology $21: 329-343$.

Boivin, N.

2004 Landscape and cosmology in the South Indian Neolithic: New perspectives on the Deccan ashmounds. Cambridge Archaeological Journal 14(2): 235-257.

Boivin, N., R. Korisettar, and D. Fuller

2005 Further research on the Southern Neolithic and the ashmound tradition: The Sanganakallu-Kupgal Archaeological Research Project interim report. Journal of Interdisciplinary Studies in History and Archaeology 2(1):59-86.

Brumm, A., N. Boivin, and R. Fullagar

2006 Signs of life: Engraved stone artefacts from Neolithic South India. Cambridge Archaeological Journal 16(2): 165-190. 
Chazan, M.

1997 Redefining Levallois. Journal of Human Evolution 33 : 719-735.

Cotterell, B., and J. Kamminga

1987 The formation of flakes. American Antiquity 52(4):675-708.

Deo, S. B., AND Z. D. ANSARI

1965 Chalcolithic Chandoli: Report on the Excavations at Chandoli, 1960. Poona (Pune), India: Deccan College Postgraduate and Research Institute.

Dobres, M. A.

2000 Technology and Social Agency. London: Blackwell.

Dufresne, A., J. G. Shaffer, M. L. Shivashankar, and Balasubramanya

1998 A preliminary analysis of microblades, blade cores and lunates from Watgal: A Southern Neolithic site. Man and Environment 23(2): 17-43.

Dunnell, R. C.

1986 Methodological issues in Americanist artifact classification. Advances in Archaeological Method and Theory 9:149-207.

EDMONDS, M.

1990 Description, understanding and the châine opératoire. Archaeological Review from Cambridge 9(1) : 55-70.

Eerkens, J. W., and R. L. Bettinger

2001 Techniques for assessing standardization in artifact assemblages: Can we scale material variability? American Antiquity 66(3): 493-504.

Foote, R. B.

1887 [1979] Notes on some recent Neolithic and Palaeolithic finds in South India, in $A$ SourceBook of Indian Archaeology, vol. 1:82-86, ed. F. R. Allchin and D. K. Chakrabarti. New Delhi: Munshiram Manoharlal.

1916 The Foote Collection of Indian Prehistoric and Protohistoric Antiquities: Notes on Their Ages and Distribution. Madras: Government Press.

Fuller, D .Q., R. Korisettar, and N. Boivin

Forth- Dating the Neolithic of South India: New radiometric evidence for key economic, social coming and ritual transformations.

Gibson, E. C.

1982 Upper Paleolithic flintknapping specialists? The evidence from Corbiac, France. Lithic Technology 11(2): 41-51.

Hampton, O. W.

1999 Culture of Stone: Sacred and Profane Uses of Stone Among the Dani. College Station: Texas A\&M University Press.

Inizan, M.-L., AND M. LeChevallier

1990 A techno-economic approach to lithics: Some examples of blade pressure debitage in the Indo-Pakistani subcontinent, in South Asian Archaeology: 43-59, ed. M. Taddei. Rome: ISMEO.

1995 Pressure debitage and heat treatment in the microlithic assemblage of Bagor, Northwest India. Man and Environment 20(2): 17-21.

1997 A transcultural phenomenon in the Chalcolithic and Bronze Age lithics of the Old World: Raw material circulation and production of standardized long blades. The example of the Indus Civilization, in South Asian Archaeology 1995, vol. 1:77-85, ed. F. R. Allchin and B. Allchin. New Delhi: Oxford \& IBH Publishing.

Inizan, M.-L., M. Lechavallier, and J. Pelegrin

1994 The use of metal in the lithics of Sheri Khan Tarakai, Pakistan: Evidence provided by the technological approach of pressure debitage, in South Asian Archaeology 1993: 245-256, ed. A. Parpola and P. Koskikallio. Helsinki: Suomalaienen Tiedeakatemia.

Inizan, M.-L., M. Lechavallier, And P. Plumet

1992 A technological marker of the penetration into North America: Pressure microblade debitage, its origin in the Paleolithic of North Asia and its diffusion. Materials Research Society Symposium Proceedings 267:661-681.

Inizan, M.-L., M. Reduron-Ballinger, H. Roche, And J. Tixier

1999 Technology and Terminology of Knapped Stone. Nanterre, France: Cercle de Recherches et d'Etudes Préhistoriques. 
Kenoyer, J. M., M. Vidale, and K. K. Bhan

1991 Contemporary stone beadmaking in Khambhat, India: Patterns of craft specialization and organization of production as reflected in the archaeological record. World Archaeology $23(1): 44-63$.

Korisettar, R., P. C. Venkatasubbaiah, and D. Q. Fuller

2001 Brahmagiri and beyond: The archaeology of the Southern Neolithic, in Indian Archaeology in Retrospect, vol. 1: Prehistory, Archaeology of South Asia: 151-236, ed. S. Settar and R. Korisettar. Monohar: Indian Council of Historical Research.

LEMONNIER, P.

1986 The study of material culture today: Toward an anthropology of technical systems. Journal of Anthropological Archaeology $5: 147-186$.

1992 Elements for an Anthropology of Technology. Ann Arbor: Museum of Anthropology, University of Michigan.

LubBock, J.

1869 Pre-Historic Times, as Illustrated by Ancient Remains, and the Manners and Customs of Modern Savages. London: Williams and Norgate.

Lyman, R. L., M. J. O’Brien, and R. C. Dunnell

1997 The Rise and Fall of Culture History. New York: Plenum Press.

Moore, M. W.

2003a Australian Aboriginal blade production methods on the Georgina River, Camooweal, Queensland. Lithic Technology 28:35-63.

$2003 \mathrm{~b}$ Australian Aboriginal biface reduction techniques on the Georgina River, Camooweal, Queensland. Australian Archaeology 56:22-34.

2003c Flexibility of stone tool manufacturing methods on the Georgina River, Camooweal, Queensland. Archaeology in Oceania 38:23-36.

2004 The tula adze: Manufacture and purpose. Antiquity $78: 61-73$.

Pelcin, A. W.

1997 The effect of indentor type on flake attributes: Evidence from a controlled experiment. Journal of Archaeological Science 24 : 613-621.

Pelegrin, J., C. Karlin, and P. Bodu

1988 Chaînes opératoires: Un outil pour le préhistorien, in Journée D'Études Technologiques en Préhistoire: 55-62, ed. J. Tixier. Paris: Éditions du CNRS.

Peregrine, P.

1991 Some political aspects of craft specialization. World Archaeology 23(1):1-11.

Pétrequin, P., ANd A.-M. Pétrequin

1993 From polished stone tool to sacred axe: The axes of the Danis of Irian Jaya, Indonesia, in The Use of Tools by Human and Non-Human Primates: 359-380, ed. A. Berthelet and J. Chavaillon. Oxford: Clarendon Press.

Pétrequin, P., A.-M. Pétrequin, F. Jeudy, C. Jeunesse, J.-L. Monnier, J. Pelegrin, And I. Praud

1998 From the raw material to the Neolithic stone axe: Production processes and social context, in Understanding the Neolithic of North-Western Europe: 277-311, ed. M. Edmonds and C. Richards. Glasgow: Cruithne Press.

Pigeot, N.

1990 Technical and social actors: Flintknapping specialists and apprentices at Magdalenian Etiolles. Archaeological Review from Cambridge 9(1):126-141.

Rosen, S. A.

1997 Lithics after the Stone Age: A Handbook of Stone Tools from the Levant. Walnut Creek, CA: Altamira Press.

Roux, V., B. Bril, And G. Dietrich

1995 Skills and learning difficulties involved in stone knapping: The case of stone-bead knapping in Khambhat, India. World Archaeology 27(1):63-87.

Sankalia, H. D.

1988 Ground and polished stone tools, in Excavations at Inamgaon, vol. 1, part 2:527-542, ed. M. K. Dhavalikar, H. D. Sankalia, and Z. D. Ansari. Pune, India: Deccan College Postgraduate Research Institute. 
Sankalia, H. D., S. B. DeO, and Z. D. Ansari

1971 Chalcolithic Navdatoli: The Excavations at Navdatoli, 1957-59. Poona (Pune), India: Baroda. SCHLANGER, N.

1996 Understanding Levallois lithic technology and cognitive archaeology. Cambridge Archaeological Journal 6(2): 231-254.

SELlet, F.

1993 Châine opératoire: The concept and its applications. Lithic Technology 18:106-112.

Shafer, H. J., AND T. R. Hester

1991 Lithic craft specialization and product distribution at the Maya site of Colha, Belize. World Archaeology 23(1): 79-97.

Sнотт, M. J.

2003 Châine opératoire and reduction sequence. Lithic Technology 28(2): 95-105.

STAFFORD, M.

2003 The parallel-flaked flint daggers of Late Neolithic Denmark: An experimental perspective. Journal of Archaeological Science 30:1537-1550.

Stout, D.

2002 Skill and cognition in stone tool production: An ethnographic case study from Irian Jaya. Current Anthropology 43(5) : 693-722.

Subbarao, B.

1948 Stone Age Cultures of Bellary. Poona (Pune), India: Deccan College.

Toth, N., D. Clark, and G. Ligabue

1992 The last stone ax makers. Scientific American July: 88-93.

Trigger, B. G.

1989 A History of Archaeological Thought. Cambridge: Cambridge University Press.

VAnPoOl, T. L., AND R. D. LeOnARD

2002 Specialized ground stone production in the Casas Grandes region of northern Chihuahua, Mexico. American Antiquity 67(4): 710-730.

WHEELER, M.

1959 Early India and Pakistan to Ashoka. London: Thames and Hudson.

WheELER, R. E. M

1948 Brahmagiri and Chandravalli 1947: Megalithic and other cultures in the Chitaldrug District, Mysore State. Ancient India 4 : 180-310.

WhitTAKer, J. C.

1994 Flintknapping: Making and Understanding Stone Tools. Austin: University of Texas Press.

Worman, E. C.

1949 The "Neolithic" problem in the prehistory of India. Journal of the Washington Academy of Sciences 39(6): 181-201.

\section{ABSTRACT}

This essay discusses the preliminary results of recent archaeological investigations into stone axe production and exchange processes at a Neolithic hilltop settlement in South India. The site in question comprises a stone-lined circular structure situated on a plateau area on the side of a topographically complex hill, known locally as Hiregudda. Across the plateau, extensive surface scatters of flaked dolerite material indicate a heavy focus on edge-ground bifacial axe manufacture at the site. Excavation of the structure and its immediate surrounds has revealed stratified deposits of dolerite axes, axe blanks and debitage, as well as a large lithic dumping area adjacent to the structure. Several clusters of axe-grinding grooves are documented on granite boulders and bedrock exposures both in and around the structure, and at least two intensively quarried outcrops of dolerite have been recorded within close vicinity of the plateau. Following a detailed examination of the axe manufacturing technology employed by knappers in the "workshop" structure, we suggest that the evidence for large-scale quarrying and industrial activity at Hiregudda points to 
the importance of this hilltop settlement in the axe production and exchange network of Neolithic South India. We present radiocarbon dating evidence from our investigations that implies the most intensive phase of axe manufacture and possibly distribution at Hiregudda took place during the Late Neolithic-Megalithic transition around the thirteenth or fourteenth millennia B.C. KEywords: Southern Neolithic, India, stone axes, technology, production, exchange, Neolithic-Megalithic transition. 
Reproduced with permission of the copyright owner. Further reproduction prohibited without permission. 